\title{
LOGÍSTICA DE TRANSPORTES E EXPORTAÇÕES DE CAFÉ NO ESTADO DE MINAS GERAIS, BRASIL
}

\author{
PATRICK PEREIRA DE JESUS
}

Mestre em Geografia, Programa de Pós-Graduação em Geografia Universidade Estadual de Montes Claros, Montes Claros - MG ${ }^{1}$

patrickpereiradejesus@gmail.com

\section{LUIZ ANDREI GONÇALVES PEREIRA}

Doutor em Geografia, Docente dos cursos de Graduação e Pós-Graduação em Geografia, Universidade Estadual de Montes Claros, Montes Claros - MG ${ }^{1}$

\section{luizandreigoncalves@yahoo.com.br}

\begin{abstract}
RESUMO: No mercado internacional, a logística de transportes tornou-se um elemento-chave e indispensável na organização territorial das atividades empresariais, incluindo o segmento de commodities agrícolas. As estruturas produtivas e de comercialização de produtos exportáveis como o café, que é demandado nos mercados internacionais, buscam os serviços de transportes especializados para interconectar os mercados. O objetivo deste artigo é analisar as interações espaciais da infraestrutura dos serviços logísticos de transportes na movimentação do café produzido em Minas Gerais e que é exportado para os mercados internacionais, considerando as áreas produtivas, os recintos alfandegados e os transportes internacionais, no período de 1997 a 2018. Realizaram-se a revisão de literatura, a coleta e a organização de dados disponibilizados pelas instituições públicas brasileiras. As empresas exportadoras transportam o café pelo território nacional, utilizando o modal rodoviário, que concentram os fluxos nos portos e no transporte marítimo com destino aos mercados globais.
\end{abstract}

Palavras-chave: Logística de transportes; exportações; café; mercados globais.

\section{TRANSPORT LOGISTICS AND COFFEE EXPORTS IN THE STATE OF MINAS GERAIS, BRAZIL}

ABSTRACT: In the international market, transport logistics has become a key and indispensable element in the territorial organization of business activities, including the agricultural commodities segment. The productive and commercial structures of exportable products such as coffee, which is demanded in international markets, seek specialized transport services to interconnect markets. The objective of this article is to analyze the spatial interactions of the infrastructure of logistical transport services in the movement of coffee produced in Minas Gerais and which is exported to international markets, considering the productive areas, customs areas and international transport, in the period of 1997 to 2018. Literature review, data collection and organization made available by Brazilian public institutions was carried out. Exporting companies transport coffee across the national territory using the road modal, which concentrate flows in ports and maritime transport bound for global markets.

Key words: Transport logistics; exports; coffee; global markets.

\section{LOGÍSTICA DE TRANSPORTE Y EXPORTACIÓN DE CAFÉ EN EL ESTADO DE MINAS GERAIS, BRASIL}

RESUMEN: En el mercado internacional, la logística del transporte se ha convertido en un elemento clave e indispensable en la organización territorial de las actividades empresariales, incluido el segmento de commodities agrícolas. Las estructuras productivas y comerciales de productos exportables como el café, que se demanda en los mercados internacionales, buscan servicios de transporte especializados para interconectar mercados. El objetivo de este artículo es analizar las interacciones espaciales de la infraestructura de los servicios de transporte logístico en el movimiento del café producido en Minas Gerais y que se exporta a los mercados internacionales, considerando las áreas productivas, áreas aduaneras y transporte internacional, en el período de 1997. a 2018. Se realizó revisión de la literatura, recolección de datos y organización puesta a disposición por las instituciones públicas brasileñas. Las empresas exportadoras transportan café por todo el territorio nacional utilizando el modal por carretera, que concentra flujos en puertos y transporte marítimo con destino a los mercados globales.

Palabras clave: Logística de transporte; exportaciones; café; mercados globales.

${ }^{1}$ Endereço para correspondência: Campus Universitário Professor Darcy Ribeiro, Avenida Rui Braga, s.n., Vila Mauricéia, CEP: 39401-089 - Montes Claros-MG.

Patrick Pereira de Jesus e Luiz Andrei Gonçalves Pereira. Logística de transportes e exportações de café no estado de Minas Gerais, Brasil Brazilian Geographical Journal: Geosciences and Humanities research medium.

Ituiutaba, v. 11, n. 1, p. 214-239, jan./jul. 2020.

Página | 214 


\section{INTRODUÇÃO}

As estruturas produtivas de commodities agrícolas, nas quais atuam os agentes econômicos (produtores, fornecedores, prestadores de serviços e empresas), estão também localizadas no território brasileiro, incluindo o estado de Minas Gerais - que é o cenário deste estudo -, demandam estratégias políticas e econômicas que resultem na formulação de políticas públicas voltadas para os estímulos das exportações, que atendem as necessidades dos mercados internacionais.

A busca por mercados cada vez mais competitivos no cenário internacional propiciou a expansão e o desenvolvimento das atividades agrícolas e das indústrias processadoras de grãos em Minas Gerais, principalmente em áreas de Cerrado, as quais buscaram atender as demandas dos mercados internos (nacionais) e dos mercados globais (CLEPS JUNIOR, 1998). Nesse contexto, a logística é incorporada como ferramenta estratégica no segmento empresarial, tornando-se aplicada nas interações e nas (re)organizações espaciais da infraestrutura e dos serviços que operacionalizam os fluxos, principalmente por meio dos transportes, com a finalidade de ampliar a circulação de produtos in natura e processados no comércio de commodities agrícolas.

Nas interações comerciais, os transportes na logística têm o papel de operacionalizar a articulação e a organização socioespacial da circulação de bens materiais, interligados aos fluxos imateriais (serviços e informações), gerenciando de forma estratégica e sincronizada os fluxos de mercadorias do segmento de commodities agrícolas. Em atividades comerciais internacionais, a logística de transportes busca medidas para superar as incertezas e as inseguranças relacionadas aos fluxos, à armazenagem e aos transbordos de mercadorias.

Esta pesquisa abordou a logística de transportes em um contexto de escoamento do café produzido no território mineiro e que é vendido nos mercados globais. As commodities agrícolas que têm grandes importâncias nos mercados internacionais, como o café, mobilizam um conjunto de ações e de investimentos de empresas nacionais e transnacionais especializadas em comercializar os produtos agrocomerciais.

Entende-se que as ações logísticas estão voltadas às atividades que exercem maior dinâmica comercial. O setor agrícola em Minas Gerais é constituído por vários tipos de insumos, porém, alguns representam valores significativos no mercado internacional agroalimentar e agroenergético. Assim, buscou-se selecionar no setor de grãos, o produto primário in natura de maior representatividade nas exportações mineiras, o café, conforme dados disponibilizados pelo Comex Stat, do Ministério da Economia.

O interesse por essa temática despertou-se mediante o fato de que, para assegurar a competitividade mineira nos mercados globais de commodities agrícolas é necessário que a logística de transportes tenha eficácia e eficiência na operacionalização dos fluxos de café, do local de produção (fazendas, armazéns e indústrias de processamento) até os recintos alfandegados nacionais e mercados globais. Este trabalho expôs a seguinte problemática de estudo: como está organizada a logística de transportes na operacionalização dos fluxos do setor agroalimentar das exportações de café de Minas Gerais para os mercados internacionais? O objetivo geral deste artigo é analisar as interações espaciais ocasionadas pela infraestrutura dos serviços logísticos de transportes na movimentação de café exportado de Minas Gerais para os mercados globais, considerando as áreas produtivas, os recintos alfandegados e os transportes internacionais, no período de 1997 a 2018.

Nesta pesquisa, os procedimentos metodológicos adotados foram divididos em duas etapas. Na primeira etapa realizou-se a revisão de literatura a fim de discutir temáticas e conceitos referentes à logística, aos transportes, às exportações, às redes de comercialização e de exportação; na segunda etapa, para a análise dos fluxos, fizeram-se a coleta e a organização dos dados disponibilizados pela plataforma virtual (site) do Comex Stat, 
vinculada ao Ministério da Economia, pelo Instituto Brasileiro de Geografia e Estatística IBGE e pelo Ministério da Infraestrutura.

Ao considerar o procedimento de coleta e organização dos dados, esses foram agrupados em categorias, seguindo o padrão internacional de identificação e classificação de mercadorias, denominado Sistema Harmonizado - SH. Os dados foram agrupados em categorias - $\mathrm{SH}_{2}$ e $\mathrm{SH}_{4}$, ou seja, o produto é identificado por meio do código o9.01 (café), composto de quatro dígitos. As nomenclaturas coletadas do produto selecionado, possibilitaram fazer o cruzamento de informações, tais como: os recintos alfandegados (portos, aeroportos e pontos de fronteiras), os meios de transportes utilizados no escoamento do produto e os mercados de destinos das exportações. Logo em seguida, utilizou-se o software Excel, versão 2010, para representar as informações da produção e exportação do produto em forma de tabela e de gráfico. Também foram construídos mapas temáticos no software ArcGis 10.2, para representar espacialmente os fluxos das exportações (café em grão) por meio dos recintos alfandegados (portos, aeroportos e pontos de fronteira), por transportes internacionais e por mercados globais agrupados em blocos econômicos.

\section{Logística agroindustrial: produção e comercialização de commodities agrícolas}

Na abordagem socioeconômica do espaço geográfico compreende-se que as atividades agrícolas exercem ações no território que se materializam, não apenas pelas unidades de produção, de comercialização e armazenamento, mas também pela representação das áreas em que os mercados se estabelecem (FAJARDO, 2011). No setor agroindustrial, grandes grupos econômicos atuam não somente na cadeia produtiva, mas também controlam os mercados. Cada vez mais, empresas do setor agroindustrial (cooperativas agropecuárias e tradings) manifestam a disputa pela produção e comercialização dos produtos.

$\mathrm{Na}$ comercialização do setor do agronegócio, as empresas (tradings companies) e cooperativas (agropecuárias, agroindustriais e comerciais) operacionalizam a cadeia de insumos, a cadeia produtiva e as redes de distribuição, que englobam a movimentação de matérias-primas, de fabricação dos produtos e a entrega dos produtos ao consumidor final (PEREIRA; OLIVEIRA, 2019). Nos mercados de commodities agrícolas, Waquil, Miele e Schultz (2010) pontuam que os produtos agropecuários, em seu processo de comercialização, são caracterizados por meio de produtos in natura e de produtos com baixo grau de industrialização, apresentando uma baixa forma de diferenciação na estrutura deles, enquanto os produtos especiais são constituídos por um elevado processo de industrialização e de diferenciação.

O termo "commodities" é uma expressão do inglês que significa "qualquer mercadoria" ou "uma mercadoria qualquer" que passou a ser utilizado no mercado financeiro, especialmente em bolsas de valores, para fazer referência a produtos de baixo valor agregado, processados ou não nas transações comerciais. Nas palavras de Frederico (2011, p. 10), as commodities são definidas a partir de "uma mercadoria primária ou semielaborada, mineral ou agrícola, padronizada e produzida em grandes quantidades, com cotações e transações mundiais, reguladas pelas principais bolsas de mercadorias [...]”. Para Frederico (2011), as transações internacionais de commodities ocorrem pelo estabelecimento de produtos padronizados, que os produtores e vendedores (empresas e cooperativas) comercializam diretamente com as empresas atacadistas e varejistas, enquanto as tradings companies também podem ser as intermediadoras das vendas, comprando a produção dos produtores e comercializando com as redes distribuidoras.

As commodities são mercadorias que apresentam características genéricas, com pouca diferenciação em sua estrutura produtiva, geralmente comercializadas a granel e não têm marcas específicas que agregam valores aos produtos. Nos mercados de produtos agroalimentares, por um lado, existem as commodities comercializadas na forma in natura 
(sem processamento), destacando-se os grãos como arroz, trigo, cevada, milho, sorgo, feijão, soja, café etc. E, por outro lado, existem as commodities processadas, nas quais se destacam o farelo de soja, o óleo de soja, o suco de laranja, o açúcar, o etanol, o fumo, entre outras (MORALES, 2008; WAQUIL; MIELE; SCHULTZ, 2010). Esses produtos formam a base na estrutura das cadeias produtivas do agronegócio que, por sua vez, possuem o fator preço, como principal determinante na sua compra, que sofre as variações nas negociações em conformidade com as regras do mercado.

No funcionamento dos mercados no comércio internacional, Morales (2008) destaca a importância das commodities agrícolas e minerais na economia, incorporando a balança comercial e o crescimento do Produto Interno Bruto (PIB). Especialmente em mercados de produtos agrícolas, a estrutura produtiva e a atividade de comercialização também influenciam na implantação de agroindústrias, bem como na prestação de serviços de comunicação, de transportes e de armazenamento. De modo que as bases produtivas dependem do uso de matérias-primas, estimulando a fabricação e a comercialização de produtos entre os países, inter-relacionando com os mercados financeiros no financiamento e nas transações financeiras realizadas.

$\mathrm{Na}$ caracterização dos mercados financeiros de commodities agrícolas é importante considerar o papel de cada agente econômico dentro da dinâmica de comercialização. Conforme destaca Waquil; Miele e Schultz (2010), para caracterizar o mercado de commodities agrícolas faz-se necessário levar em consideração a abrangência geográfica desses mercados. Nas dinâmicas desses, as commodities precisam de estruturas para serem estocadas, transacionadas e distribuídas internacionalmente, incorporando, assim, uma demanda de fluxos em escalas locais e regionais, nacionais e internacionais, uma vez que os compradores e os vendedores de produtos agrícolas podem ser constituídos por grupos de indivíduos, de empresas privadas e estatais, de cooperativas agroindustriais e de prestadores de serviços públicos (municipal, estadual e federal) e privados.

Nos mercados globais de commodities agrícolas, Pereira e Oliveira (2019) pontuam a existência de companhias especializadas na produção, na comercialização e na prestação de serviços voltadas para os setores agropecuários. A atuação de grandes corporações multinacionais ocorre de forma estratégica nos territórios, visto que elas podem distribuir e gerenciar os seus negócios de forma simultânea em todo o mundo. As empresas agroalimentares, com destaque para as tradings companies multinacionais, promovem ações no sistema financeiro que se refletem no controle de preços, na oferta e na demanda de commodities agrícolas in natura e processadas nos mercados globais.

No mercado agrícola, grupos como as tradings companies e as agroindústrias nacionais e multinacionais, assim como as cooperativas agroindustriais estabelecem uma interdependência em toda a cadeia de produção e de comercialização. Entretanto, há um grau de subordinação que caracteriza a maneira como a empresa se comporta na inserção no mercado internacional. As tradings companies que comercializam e processam produtos agroalimentares estabelecem uma relação socioeconômica para que as cooperativas e os produtores agrícolas sejam fornecedores de insumos. Dessa forma, essas empresas (tradings companies) orientam e direcionam a estrutura produtiva, impondo os preços e as condições de produção (ALBUQUERQUE; GARCIA, 1988).

De acordo com Albuquerque e Garcia (1988), as tradings (grandes agroindústrias) estabelecem normas para as cooperativas e para os produtores se tornarem fornecedores de insumos, no tocante ao uso de insumos químicos e as formas de processamento dos produtos, de armazenagem, de transporte, entre outras. Desse modo, o mercado é caracterizado pela subordinação e interdependência de grupos que atuam de forma estratégica, visando atender às demandas dos consumidores nacionais e internacionais e estabelecer a lucratividade. Conforme aponta Fajardo (2007), em proporção menor que as tradings companies, as grandes cooperativas brasileiras inserem os seus produtos no mercado internacional, exportando para mais de 135 países, dos quais se destacam a China, 
os Emirados Árabes, a Alemanha, os Estados Unidos, a Nigéria, a Arábia Saudita, a África do Sul, a França, o Marrocos, entre outros. Assim, embora haja diferença entre empresas multinacionais e grandes cooperativas brasileiras, ambas competem praticamente pelos mesmos mercados.

No Brasil, os acordos regionais - bilaterais e multilaterais - são regulados pelo Ministério da Agricultura, Pecuária e Abastecimento (MAPA) responsável pelo posicionamento nas negociações agrícolas internacionais. No cenário das exportações brasileiras, o Brasil se confronta muitas vezes com o protecionismo de alguns países com o qual o Mercado Comum do Sul (MERCOSUL) tem negociações. Ao longo dos anos, as ações governamentais buscaram desenvolver um direcionamento nas políticas agrícolas brasileiras apostando cada vez mais na liberação dos mercados internacionais (MEDINA, 2017). Para esse autor, a redução do protecionismo pode aumentar o mercado internacional, beneficiando todos os países membros da Organização Mundial do Comércio (OMC).

Entende-se que investimentos em políticas agrícolas se tornaram imprescindíveis no comércio internacional, tendo em vista que países buscam cada vez garantir competitividade nos mercados. Nas exportações de commodities agrícolas, a logística por meio dos serviços tem um papel importante nas interconexões espaciais entre as estruturas produtivas e os mercados internacionais, pontos que serão vistos na próxima seção.

\section{Logística agroindustrial: produção e comercialização de commodities agrícolas}

Na fase contemporânea de "circulação de capital", as exigências dos clientes, em termos de continuidade dos fluxos, de pontualidade e de integridade das cargas, dependem de serviços logísticos cada vez mais sofisticados. As atividades ligadas à logística de transportes, durante séculos, eram exercidas no cotidiano das corporações e da sociedade, principalmente, no transporte de materiais, de alimentos e de equipamentos ou, mais tarde, nos deslocamentos de pessoas (MONIÉ, 2011). Dessa forma, o conceito de logística evoluiu no segmento empresarial e no âmbito governamental. Conforme Barat (2012), a logística passou a ser incorporada nas atividades das empresas e na agenda de planejamento governamental em razão das necessidades de escoamento de mercadorias destinadas às exportações, ao abastecimento do mercado interno, também aos processos de estocagem em processo estratégico de distribuição dos produtos.

Para Barat (2012), a logística, nos planos de governo, implica planejar alternativas, reduzir custos, contornar as dificuldades causadas por gargalos infraestruturais e pelas ineficiências nas operações e na superação dos obstáculos institucionais, legais e burocráticos em cada uma das etapas do suprimento, do escoamento e da distribuição das mercadorias. Essas medidas devem abranger desde a coleta na origem, a estocagem, o escoamento e a distribuição no destino final, incluindo também o apoio dos sistemas de comunicação e de informática em todos os estágios de movimentação das cargas destinadas às estruturas produtivas e aos mercados.

Na concepção de Monié (2011), a logística passou a ser um componente central de planejamento, de organização, de gestão e de estratégias das corporações na mobilização de diversos tipos de recursos para prestar serviços de qualidade e com baixo custo na gestão dos fluxos físicos e de informações na integração das cadeias produtivas, de consumo, de fornecimento de insumos, de fabricação e distribuição por meio do gerenciamento da cadeia de suprimentos.

A logística tornou-se um serviço precioso e indispensável para a competitividade das empresas nos mercados globais, assumindo aspectos específicos, em segmentos como a logística de transportes, a logística de armazenagem, a logística reversa e a logística internacional. Os serviços logísticos necessitam de um conjunto de competências infraestruturais (transportes, armazéns, terminais intermodais, portos secos e centro de distribuição), institucionais (normas, contratos de concessão, parcerias público-privadas, agências reguladoras setoriais e tributação) e 
estratégicas em conhecimento especializado na viabilização da fluidez de bens e de serviços das empresas nos mercados (CASTILLO, 2004, 2007, 2010).

As operações logísticas são essenciais para os mercados exportador e importador, uma vez que a competitividade das empresas depende da qualidade dos serviços logísticos. Ao fazer uma abordagem da logística agroindustrial de commodities agrícolas, Lourenço (2009) considera que nas exportações as operações logísticas podem ser classificadas em três etapas distintas, sendo elas: $1^{a}$ ) a logística de suprimentos que tem como objetivo gerenciar os fluxos de matéria-prima e de produtos até os locais de produção e comercialização, de forma que as operações de produção possam ocorrer no menor tempo e custo possível; $2^{\mathrm{a}}$ ) a logística de operações de apoio, responsável por integrar todos os agentes econômicos que participam direta e indiretamente da cadeia produtiva agroindustrial, tais como: fornecedores de insumos, de máquinas e equipamentos, armazenagem, indústrias de processamento, o setor de distribuição e comercialização, incluindo também o consumidor final; $3^{\text {a }}$ a logística de distribuição que incorpora nas movimentações dos produtos agroindustriais as operações e/ou serviços de transportes, burocráticos, entre outros.

$\mathrm{Na}$ cadeia agroindustrial de commodities agrícolas, as principais empresas do agronegócio global estão instaladas estrategicamente nas principais áreas de produção mundial. $\mathrm{O}$ vínculo das atividades agroindustriais com a infraestrutura dos territórios emerge por parte das empresas e do Estado no processo de planejamento e de ações voltadas para o funcionamento dos setores produtivos. Nesse contexto, surgiu a logística agroindustrial que incorporou os subsistemas de suprimentos, de apoio à produção e de distribuição dos produtos nos mercados (LIMA, 2015).

Nos sistemas agroindustriais, a competitividade acirrada das empresas no controle dos circuitos espaciais produtivos mobiliza ações voltadas para investimentos em logística. Assim, cabe aqui salientar que, no cultivo de commodities agrícolas, a dinâmica de produção e comercialização só ocorre devido à presença de empresas, que não se envolvem diretamente na atividade de produção, mas realizam a comercialização (compra e venda) e o processamento do que é produzido (PEREIRA, 2012). Os autores Cunha (2015), Fajardo (2011) e Frederico (2011) consideram que o modelo de produção agroalimentar é controlado por poucas empresas multinacionais, processo o qual os autores denominam de "oligopolização" do setor agroindustrial. Isso significa que a base produtiva atual recebe grandes investimentos de capital privado na estruturação do território agrícola, fundamentada na seletividade.

Nessa lógica, nos sistemas agroindustriais, a produção e a comercialização de commodities agrícolas mundiais e brasileiras são controladas por quatro principais grandes grupos empresariais multinacionais, sendo eles: a Archer Daniels Midland - ADM (EUA), Bunge (Holanda), Cargill (EUA) e Louis Dreyfus Company - LDC (França), conhecidas no segmento (agro)industrial com a sigla ABCD. Essas empresas internacionais denominadas de tradings são mais flexíveis do que o Estado no que tange a suas relações com o espaço geográfico. Elas atravessam fronteiras sem estabelecer qualquer compromisso com o território ou região. Diferentemente do Estado, que tem responsabilidade com o território, as tradings apenas visam à lucratividade, viabilizada pelas atividades socioeconômicas desenvolvidas nos lugares, que são usados por essas empresas para aumentar a competitividade e expandir seus mercados. Essas grandes empresas que atuam no segmento agroindustrial de produção de grãos mobilizam agentes no mundo todo (fabricantes de insumos, operadores de transportes, agricultores, bolsas de mercadorias, governos locais e nacionais, entre outros), de forma que os fluxos de produtos e informações surjam nos territórios (PEREIRA; OLIVEIRA, 2019).

Com a presença desses grandes grupos do agronegócio, o território brasileiro se torna altamente especializado e eficiente na produção e fluidez de commodities agrícolas. A ação dessas empresas, no Brasil, se materializa nos investimentos em infraestrutura e logística para que haja fluidez na comercialização dos produtos no âmbito nacional e principalmente 
no global. Para que os serviços logísticos possam ocorrer na cadeia de produção e comercialização, é necessária a presença das redes geográficas. Nos territórios, a dinâmica de fluxos materiais e imateriais só ocorre no período atual devido às redes geográficas, fenômeno denominado de "organização em rede" em substituição ao complexo agroindustrial (CASTILLO, 2004; CASTILLO, 2005; CASTILLO, 2010).

No caso das redes de infraestruturas logísticas, os grandes grupos econômicos do agronegócio investem no território brasileiro bilhões de reais em estruturas de armazenagem (armazéns e silos) e transportes (estradas, ferrovias, hidrovias, portos, entre outros) para dinamizar o escoamento dos produtos. Além disso, na última década, o Estado, em parceria com a iniciativa privada, tem buscado estratégias de macrologística para resolver os gargalos da infraestrutura de transportes do Brasil. Nessa lógica, além dos grupos econômicos que atuam na cadeia do agronegócio, surgem outros voltados especificamente para a logística de transportes. São as empresas de operações logísticas que nas últimas décadas estão atuando cada vez mais na organização dos fluxos de transportes e armazenagem no território brasileiro (CASTILLO, 2010). No caso da movimentação de grãos, as empresas de logística integrada atuam no território transportando milhões de toneladas de produtos agrícolas. Atualmente, a maioria das empresas operadoras de logística que atuam no escoamento de produtos agrícolas é de base ferroviária. As principais empresas de logística ferroviária (VLI, Rumo, FTC, MRS, TLSA e Vale) transportam cargas de minério e de produtos agrícolas por todo o país. Essas empresas são muito importantes na logística de escoamento de produtos agrícola, pois essas investem em infraestruturas de transportes e de armazenagem no território brasileiro. Diante das discussões sobre o papel da logística na comercialização de produtos, faz-se necessário fazer uma abordagem da distribuição espacial das atividades agrícolas mineiras, principalmente, a concentração da produção e comercialização de café no Brasil e em Minas Gerais, pontos que serão discutidos na próxima seção.

\section{Modernização e expansão agrícola em Minas Gerais: dinâmicas espaciais do café a granel}

No cenário de especialização produtiva, Castillo $(2004,2005,2010)$ apresenta esse fenômeno como sendo marcado pela expansão de áreas, as quais o autor denomina de novos "fronts agrícolas", que são áreas de grande produção e especialização, representando uma acentuada formação de monoculturas para exportação. Os novos fronts agrícolas são mais distantes dos principais centros consumidores (Região Concentrada) e dos portos exportadores (Santos e Paranaguá) que as áreas de produção mais antigas do Sul e Sudeste do Brasil. Essas novas áreas ocupadas localizam-se principalmente na porção setentrional do Cerrado (CASTILLO, 2005; FREDERICO, 2011). Essas novas regiões ganharam importância por produzir milhões de toneladas de grãos, cujas empresas e produtores pressionam mais para melhoria da infraestrutura de transportes e para o escoamento da produção das áreas que estão cada vez mais distantes dos centros consumidores e dos portos exportadores.

O padrão de especialização da produção mineira está correlacionado com a emergência dos fronts agrícolas, uma vez que as atividades agropecuárias adentram a área de domínio do Cerrado, nas regiões do Triângulo Mineiro, Alto Paranaíba, Sul/Sudoeste e Noroeste de Minas. Os autores Bastos e Gomes (2011) pontuam que as políticas agrícolas de desenvolvimento e a expansão dos mercados agrícolas mineiros produziram resultados diferentes nas regiões e nos produtos. Os investimentos e os projetos públicos de desenvolvimento rural ficaram concentrados principalmente a oeste e sudoeste de Minas Gerais (Sul, Triângulo/Alto Paranaíba, parte do Noroeste e Alto São Francisco). Por sua vez, os investimentos nessas regiões produziram uma agricultura mais tecnificada e integrada à indústria. Nesse sentido, a modernização do território mineiro foi parcial, pois não promoveu 
o desenvolvimento de todo estado. Além disso, o desenvolvimento da produção priorizou o setor de commodities.

Considerando a produção moderna como expressão da era da globalização, entendese como região competitiva uma área caracterizada pela especialização produtiva obediente a parâmetros internacionais de qualidade e de custo. Essas regiões são consideradas competitivas pelo alto grau de atração de investimentos públicos e privados, transformando outros locais em áreas de exclusão (SANTOS, 1997; CASTILLO, 2010). Na argumentação acerca das regiões competitivas, Castillo (2010) pontua que a competitividade deixou de ser um atributo, não somente das empresas, mas também se tornou um atributo dos lugares, das regiões e dos territórios. A competitividade deriva das formas materiais do espaço (acessibilidade, infraestruturas produtivas, de circulação, comunicação, energia elétrica, abastecimento de água, sistemas de armazenamento, terminais multimodais) e de sistemas normativos (benefícios fiscais, incentivos a partir de recursos públicos locais, acordos entre instituições de pesquisa e empresas, entre outros).

No caso das regiões competitivas agrícolas, o exemplo mais emblemático é o do setor de commodities agrícolas. Frederico (2011) considera que a especialização produtiva do território brasileiro é evidenciada pelo fenômeno o qual denomina-se "commoditização". No período atual, o território brasileiro passa por uma "commoditização" não só da economia, mas também do território, de forma que as regiões estão cada vez mais atraindo investimentos públicos e privados, além de reunirem uma série de infraestruturas e normas que as tornam funcionais a uma determinada produção e à lógica do mercado globalizado.

No contexto da modernização do território por meio da agricultura, segundo Matos e Pessôa (2011), o Estado também direcionou as políticas de investimentos para a infraestrutura de transportes e energia, concessão de incentivos fiscais e linhas de créditos que resultou na centralização do capital industrial, incluindo as grandes e médias propriedades rurais, que reorganizaram a produção agropecuária mineira nos moldes dos complexos agroindustriais.

A expansão da modernização da agricultura para as áreas de Cerrados, conforme Matos e Pessôa (2011), foi estimulada pelas ações estatais, a partir da década de 1970, quando incorporaram as atividades agropecuárias na dinâmica capitalista. Nas palavras de Cleps Junior (1998), a dinamicidade da agricultura mineira teve uma relação com a sua expansão para as áreas de Cerrado, no momento em que o Estado incentivou pesquisas para a correção de solos e adaptação de novos cultivos na agricultura mineira. Em 1971, a criação da Embrapa foi importante propagadora da modernização agrícola no Cerrado mineiro. Ela passou a coordenar e desenvolver as pesquisas científicas destinadas ao melhoramento da produção agropecuária por meio da correção das deficiências fisioquímicas dos solos e da prevenção de doenças (pragas), buscando aumentar o rendimento de produção por hectare (MATOS; PESSÔA, 2011).

$\mathrm{Na}$ distribuição espacial das atividades agropecuárias mineiras, nas mesorregiões do Triângulo Mineiro/Alto Paranaíba e Sul de Minas predominam o agronegócio, principalmente em médias e grandes propriedades, destacando-se a pecuária de corte e os cultivos de cana-de-açúcar e grãos (principalmente soja) no Triângulo Mineiro, e o café na porção sudoeste. Vale ressaltar que essas regiões de predomínio do agronegócio, principalmente no cultivo de grãos, possuem intensa especialização direcionadas à produção para o mercado agroexportador (PEREIRA; HESPANHOL, 2015). É importante destacar que a produção e a comercialização de café no Triângulo Mineiro/Alto Paranaíba e Sul de Minas produzem competitividade ao mercado mineiro frente às exportações agrícolas.

Atualmente, o Brasil é o maior produtor e exportador de café do mundo, bem como o segundo maior consumidor da bebida. Isso ocorre devido à diversidade de regiões ocupadas pela cultura cafeeira e à variedade de climas e relevos do país. As duas principais espécies plantadas no território brasileiro são o Coffea arábica (arábica) e o Coffea canephora (conilon ou robusta) (CONAB, 2018). O café tipo arábica possui uma qualidade superior a do tipo conilon, sendo de ampla apreciação mundial, por ser fino e mais sofisticado. Já o tipo 
canephora é mais utilizado por redes de cafés solúveis, tendo em vista que possui um sabor mais intenso e único que o diferencia do arábica (MACHADO, 2018).

$\mathrm{Na}$ estrutura produtiva do café, por um lado, o clima brasileiro é muito favorável para o plantio do grão em diversos estados do país. E, por outro lado, é importante considerar que as condições climáticas afetam diretamente a sua produção em grande escala. Além disso, o café pode apresentar características marcantes (cheiro, sabor, corpo e acidez) que são influenciadas pelas características físicas das regiões de plantio, das quais se destacam o relevo e o clima (MACHADO, 2018).

A produção agrícola de café do país, tanto da espécie canephora como da espécie arábica, concentra-se em 22 estados, sendo eles: Minas Gerais, Espírito Santo, São Paulo, Bahia, Paraná, Rondônia, Pará, Mato Grosso, Goiás, Rio de Janeiro, Amazonas, Ceará, Pernambuco, Mato Grosso do Sul, Acre, Distrito Federal, Santa Catarina, Paraíba, Maranhão, Tocantins, Alagoas e Piauí. No período de 1997 a 2018, seis estados representaram 97,9\% da produção acumulada de café no país, sendo eles: Minas Gerais, Espírito Santo, São Paulo, Bahia, Paraná e Rondônia. O estado de Minas Gerais é o maior produtor de café do país, correspondendo a 50\% da produção no período ora citado. Em seguida, são: Espírito Santo (23,1\%), São Paulo (10,4\%), Bahia (5,3\%), Paraná (5,0\%) e Rondônia (4,1\%). Os demais estados juntos representaram apenas 2,1\% de toda produção brasileira de café (Vide Gráfico 01).

Gráfico 01 - Produção brasileira de café em grão (1997-2018)

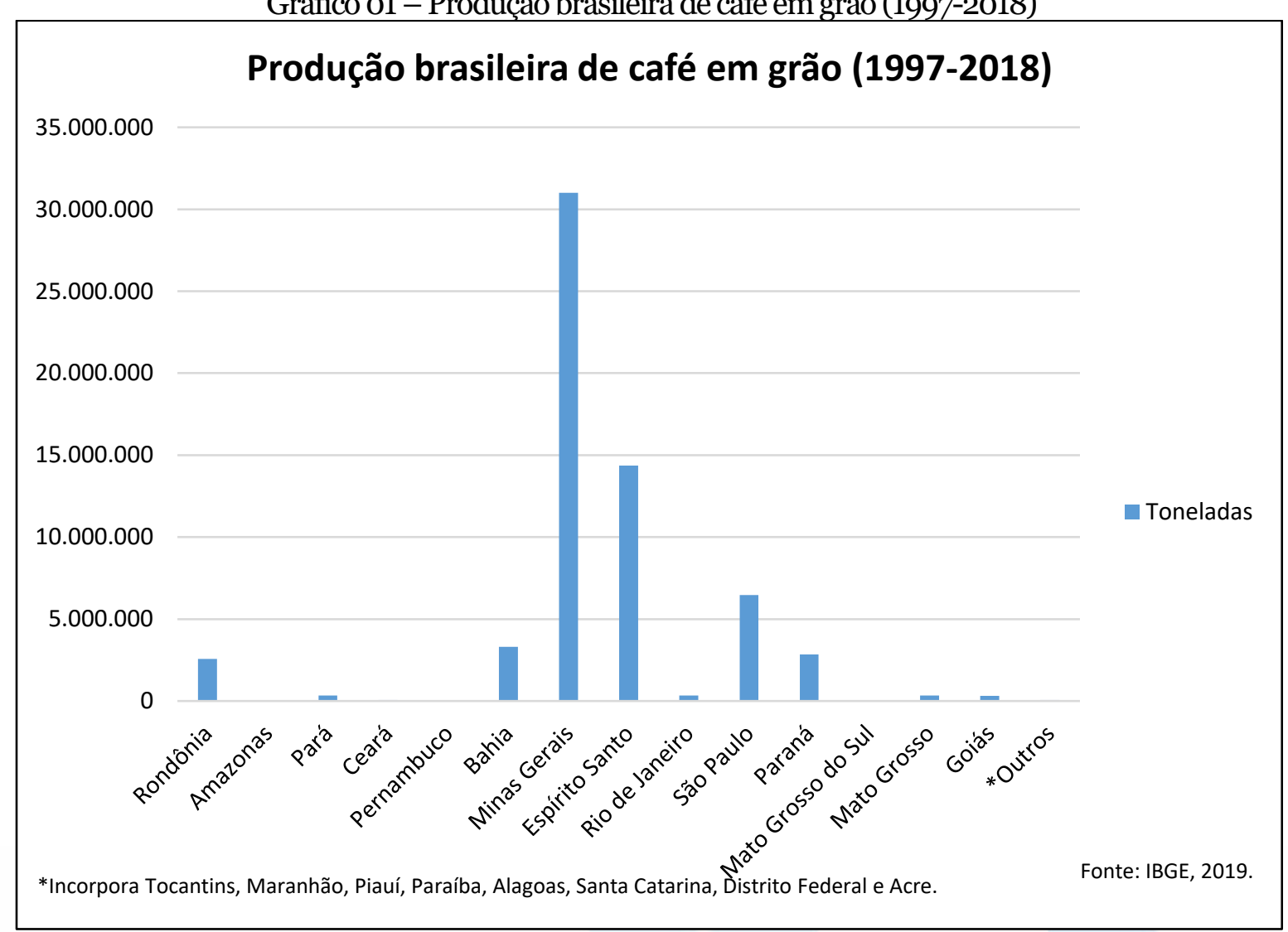

Fonte: IBGE, 2019. Org. PEREIRA DE JESUS, P., 2020.

Nas últimas duas décadas, alguns estados expandiram suas exportações de café sendo destaques no cenário das exportações do país. No período de 1997 a 2018, somente Minas Gerais concentrou 71\% dos fluxos das exportações de café em grão, em quilograma. Além de maior produtor, Minas Gerais também se destaca como sendo o maior exportador do grão do país. Isso é muito importante, pois o estado mineiro tem forte competitividade no comércio 
internacional de café. Logo depois, representando as movimentações em quantidade/quilo, vêm os estados de Espírito Santo (14\%), São Paulo (10,2\%), Paraná (2,2\%), Bahia (02\%). Os outros estados tiveram um valor pouco expressivo, ou seja, menos de $0,7 \%$ das exportações do produto. (Vide Gráfico 02).

Gráfico 02 - Brasil: exportações de café em grão, no período acumulado de 1997 a 2018

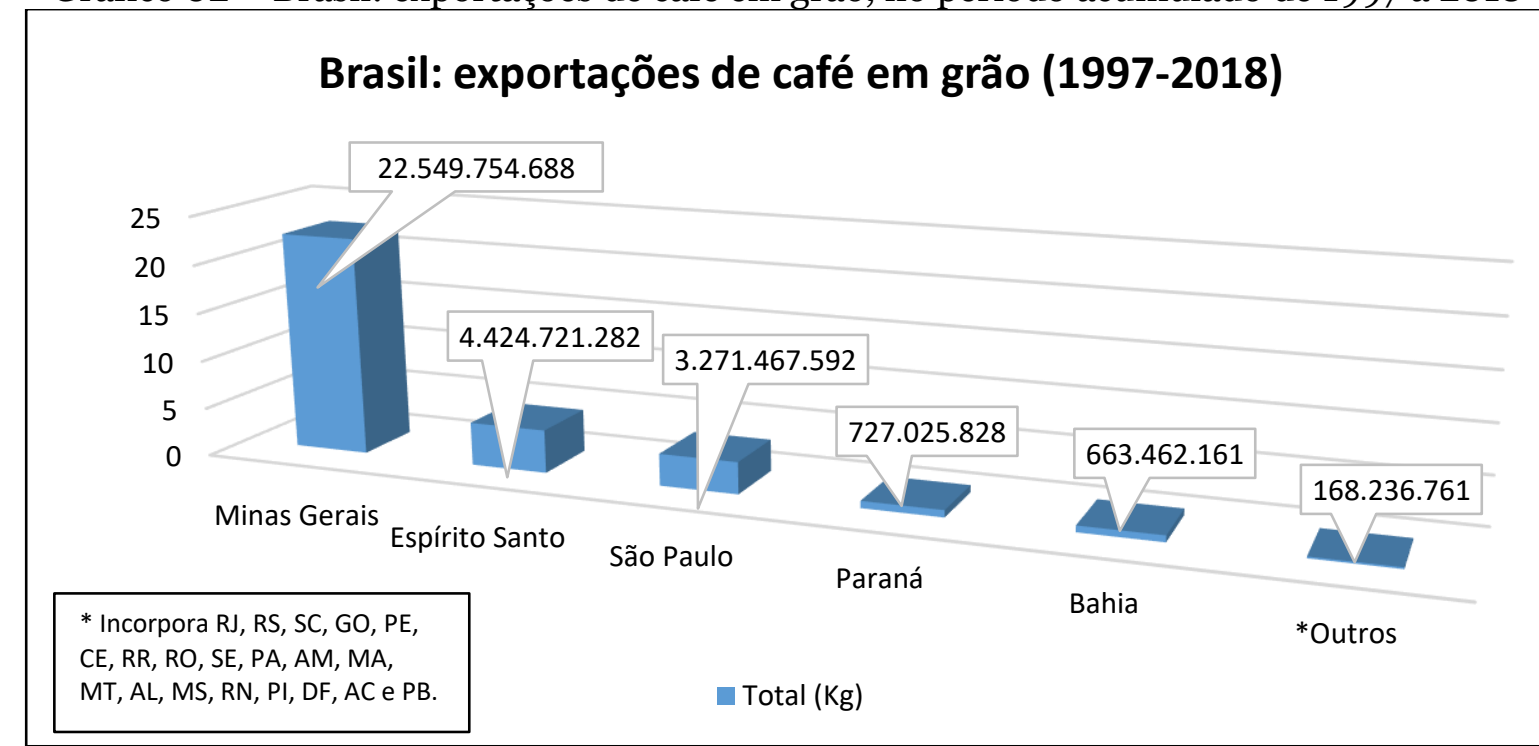

Fonte: MDIC; COMEX STAT, 1997, 1998. 1999. 2000. 2001, 2002, 2003, 2004, 2005, 2006, 2007, 2008, 2009, 2010, 2011, 2012, 2013, 2014, 2015, 2016, 2017, 2018. Org. PEREIRA DE JESUS, P., 2020.

É importante considerar que o cenário atual da cafeicultura no Brasil está historicamente relacionado com as conjunturas do ciclo de expansão do produto. Conforme destaca Pires (2007), a inserção da economia cafeeira em Minas Gerais está historicamente ligada às simetrias e assimetrias, continuidades e descontinuidades, e rupturas no contexto histórico em que a economia do produto se consolidou. Para o autor, o Brasil e Minas Gerais vivenciaram a desintegração econômica do território à medida que vigorava o declínio do setor minerador, fato que implicou o surgimento e fortalecimento de um setor de produtos primários, como o café. Com a demanda do produto, desde o final do século XVIII, o café se tornou uma das principais commodities internacionais. No século XIX, a economia cafeeira se instala e se consolida na Zona da Mata Mineira também como uma economia de produção e de exportação. Consequentemente, o produto primário transformou em uma mercadoria de consumo de massa e com forte demanda nos mercados internacionais. No século XX, em um cenário de expansão de cafeicultura, o Estado de Minas Gerais ampliou as suas áreas de produção de café, entre as unidades federativas, tornou-se o maior produtor e o maior exportador de café do Brasil.

Para melhor compreender as dinâmicas espaciais da economia cafeeira em Minas Gerais, é necessário analisar a concentração da produção de café por mesorregiões geográficas. A heterogeneidade dos aspectos e/ou fenômenos geográficos físicos e humanos do território mineiro permite identificar uma diversidade e uma concentração das atividades socioeconômicas em cada região. O território mineiro é dividido, pelo IBGE, em 12 mesorregiões, sendo elas: Norte de Minas, Noroeste de Minas, Jequitinhonha, Vale do Mucuri, Central Mineira, Vale do Rio Doce, Metropolitana de Belo Horizonte, Triângulo Mineiro/Alto Paranaíba, Oeste de Minas, Zona da Mata, Campo da Vertentes e Sul/Sudoeste de Minas (IBGE, 1990).

A produção de café em grãos em Minas Gerais, no período acumulado de 1997 a 2017, concentrou-se nas mesorregiões Sul/Sudoeste de Minas, Triângulo Mineiro/Alto Paranaíba e 
Zona da Mata, Oeste de Minas e Vale do Rio Doce. Nas demais teve pouca representatividade. Cabe destacar que, embora a produção tenha se expandido para todo o território mineiro, o crescimento não ocorrera uniformemente. As regiões do Sul/Sudoeste de Minas e Triângulo Mineiro/Alto Paranaíba, foram as que mais se sobressaíram na produção de café (Vide Mapa 01).

Mapa 01 - Produção de café em grão por mesorregiões (1997-2017)

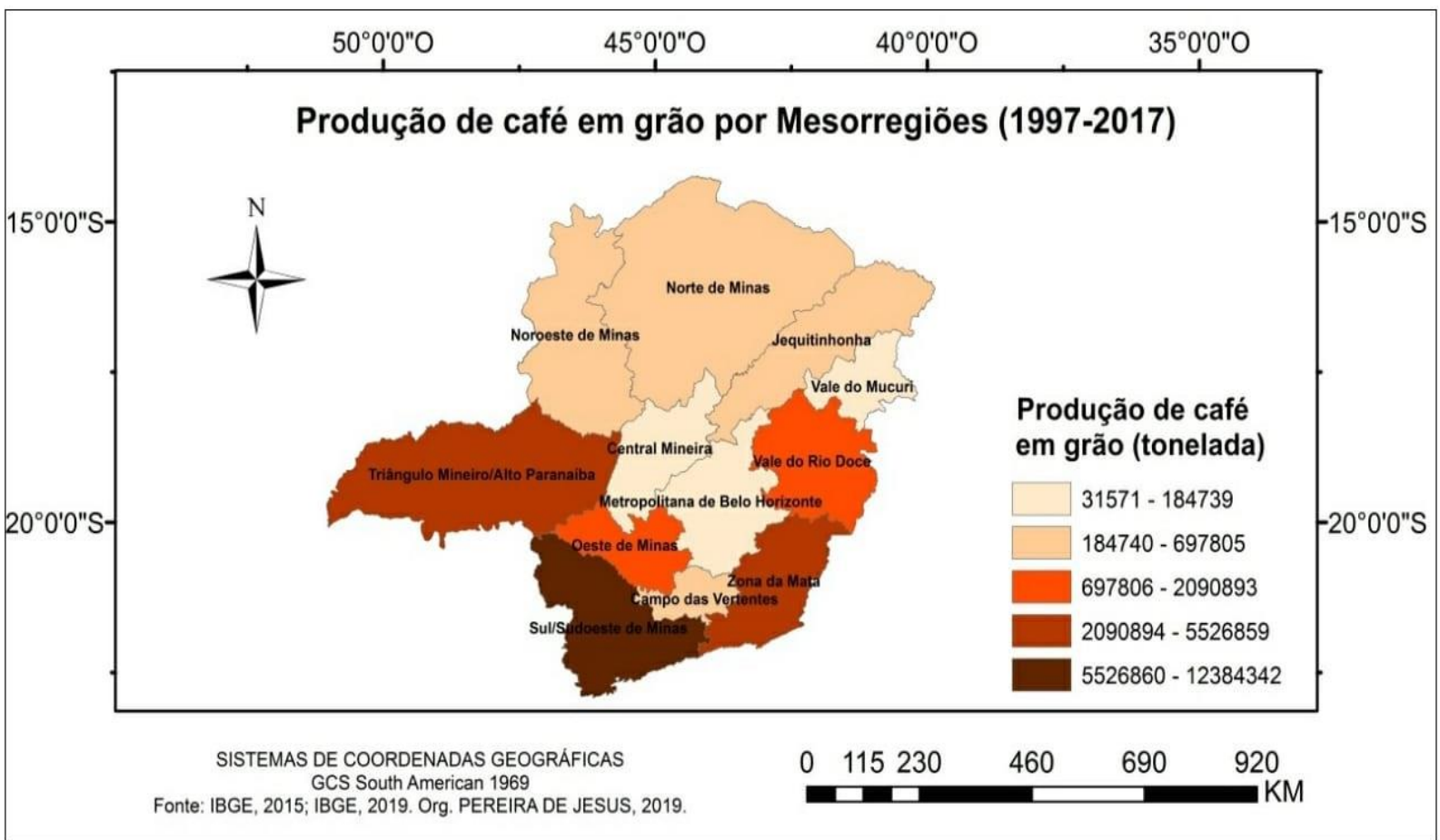

Fonte: IBGE, 2015; IBGE, 2019. Org. PEREIRA DE JESUS, P., 2020.

Ainda para melhor analisar, faz-se necessário apresentar a concentração da produção por microrregiões geográficas nas últimas duas décadas. No período acumulado, de 1997 a 2017, a produção de café se concentrou nas microrregiões de Patrocínio, São Sebastião do Paraíso, Alfenas, Varginha e Manhuaçu, sendo essas as que mais produziram no período. Além disso, outras microrregiões como Passos, Poços de Caldas, Patos de Minas e Muriaé ficaram em segundo lugar. As outras microrregiões tiveram baixa concentração (Vide Mapa 02).

De acordo com Frederico (2017), com o declínio das cafeiculturas paranaense e paulista, na década de 1970, Minas Gerais se tornou o principal estado produtor do país. No território mineiro, as plantações de café se expandiram, principalmente, para a região do Sul de Minas, Zona da Mata, Triângulo Mineiro/Alto Paranaíba, entre outras, que foram, e ainda são, as maiores regiões produtoras de café, principalmente da espécie arábica (FREDERICO, 2017). Na década de 1980, os incentivos fiscais concedidos pelo governo federal e estadual privilegiaram a instalação de indústrias de insumos no território mineiro, que também foi muito relevante na modernização e na expansão da agricultura, uma vez que existem as demandas por agroquímicos e/ou insumos agrícolas industrializados (fertilizantes, adubos etc.). Além disso, também investiu em infraestrutura de transportes, energia, telemática e de armazenagem. Para tal, criaram-se empresas de pesquisas e concederam créditos subsidiados para a ocupação de novas áreas agrícolas, com destaque para as áreas de Cerrados (CLEPS JUNIOR, 1998). 
Mapa 02 - Produção de café em grão por microrregiões (1997-2017)

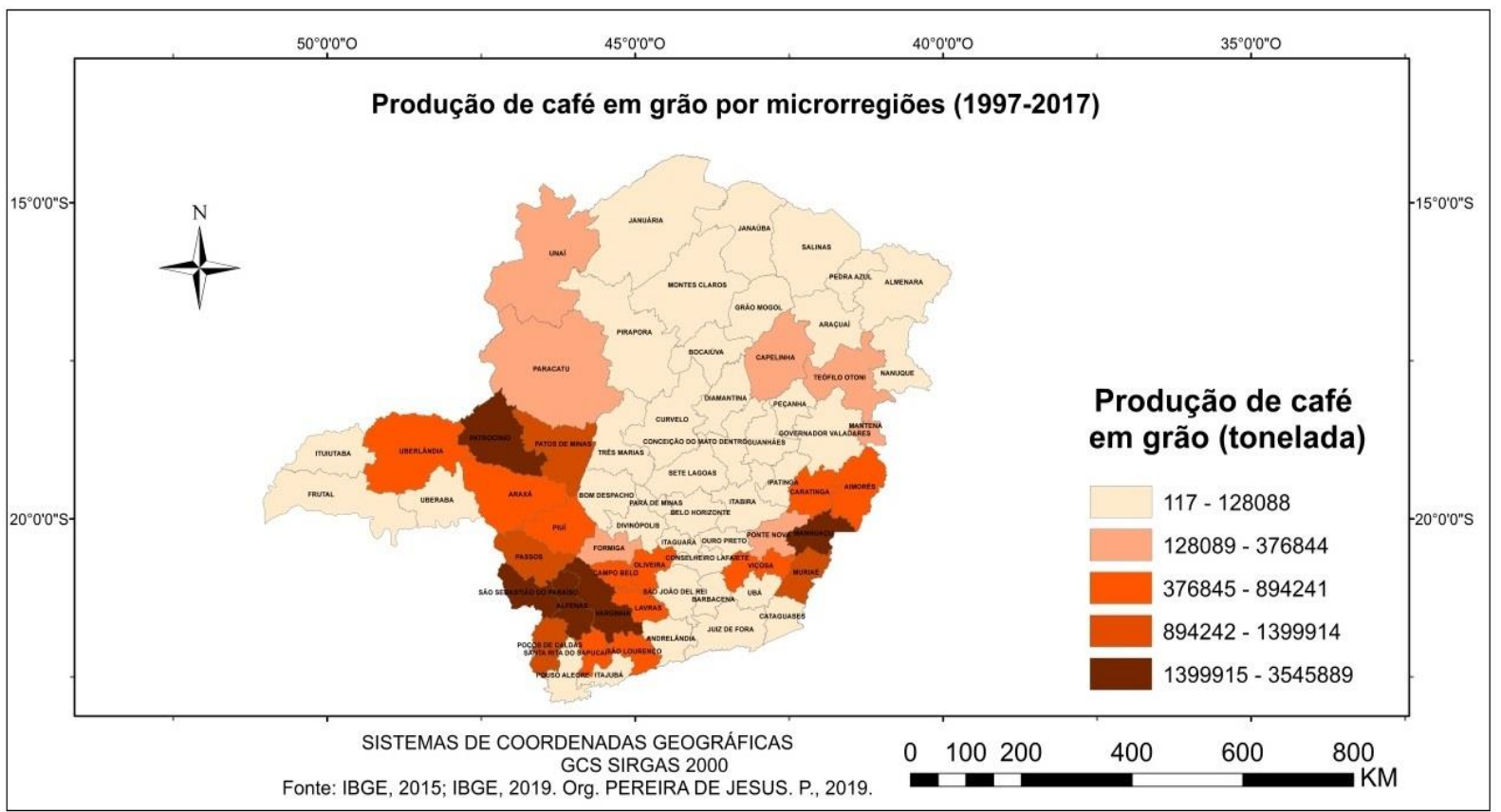

Fonte: IBGE, 2015; IBGE, 2019. Org. PEREIRA DE JESUS, P., 2020.

Nesta seção, buscou-se compreender as dinâmicas de produção e exportação de café em Minas Gerais, por meio da estrutura produtiva por regiões geográficas, com suas diversidades e particularidades, que se desenvolveram de forma concentrada em determinados espaços em Minas Gerais. É necessário fazer uma abordagem da articulação da infraestrutura do território mineiro com a logística agroindustrial de commodities agrícolas, pontos que serão discutidos na próxima seção.

\section{Movimentação de commodities agrícolas em Minas Gerais: a rede logística de transportes, a produção e as exportações de café em grão}

O estado de Minas Gerais possui uma extensão territorial de 586.520,732 km², subdividido em 853 municípios. Ele se encontra localizado na região Sudeste do país. Entre os quatro estados dessa região, é o que tem a maior extensão territorial e o quarto com território mais extenso do Brasil. Em 2010, o censo mostrou que a sua população é de 19.597.330 habitantes. Em 2018, a estimativa populacional estadual mineira é de 21.040.662 habitantes (IBGE, 2010; IBGE, 2019).

Em Minas Gerais, as empresas do agronegócio tendem a localizar-se em regiões com melhor infraestrutura, visando se beneficiarem das vantagens dos lugares, principalmente da infraestrutura de transportes, de comunicação e de sistemas de armazenamento. Se as regiões não possuem sistemas de infraestrutura ou não funcionam de maneira adequada, há um comprometimento das atividades econômicas (CAIXETA-FILHO; MARTINS, 2007). A produção e a movimentação de café necessitam de fluidez no que tange a mais velocidade, à qualidade e aos baixos custos. Quanto mais bem equipadas as regiões com redes de eletricidade, de comunicações, de silos, de armazéns e de transportes, mais propiciam um ambiente mais competitivo na região (CASTILLO, 2005).

$\mathrm{Na}$ organização dos territórios, Santos (2006) considera que as transformações do espaço são construídas e articuladas a partir das redes, (re)funcionalizam os territórios, 
determinam novas divisões do trabalho, hierarquizam os lugares e produzem novas normas e especializações territoriais. A partir daí, a organização do espaço é resultado das interações entre fixos e fluxos. Os fixos são os instrumentos materiais construídos pelas ações dos homens e com funções territoriais. Os fluxos são a circulação e os movimentos produzidos pelas ações humanas. Nesse sentido, o espaço é resultado constante das interações entre fixos e fluxos, porém, apesar das diferenças, eles são indissociáveis.

Nas interações espaciais entre os fixos e fluxos, por exemplo, uma rede ferroviária (fixos) foi construída em uma região para atender determinadas funções. Nela, serão atraídos os fluxos produzidos pelas ações humanas, que podem ser materiais (deslocamento de pessoas e mercadorias) e imateriais (circulação de energia, capital, informação e/ou comunicação, entre outros). As pessoas dão função aos fixos por meio das ações, que consequentemente levam à (re)produção dos fluxos no espaço (SANTOS, 2006). Assim, os fixos e fluxos mantêm constante interação no espaço geográfico.

As redes também são constituídas de fixos e fluxos, pois são compostas de infraestruturas e dependem dos agentes que controlam e gerenciam os fluxos que circulam e comunicam por elas. A existência das redes ocorre pela interconexão de elementos formados por nós e ligações em uma complexa dinâmica de organização do espaço. A função dos nós, ou ligações nas redes, é produzir as interações e/ou transações entre as localizações, gerando assim um intercâmbio de bens, serviços e informações (PEREIRA, 2015).

Bernardes e Ferreira (2013), ao discutirem acerca do papel das redes na logística agroindustrial mineira, consideraram que as redes podem ser definidas em dois conjuntos diferentes, destacando as redes técnicas ou de infraestrutura e as redes de serviços. A primeira é caracterizada pelo suporte aos fluxos materiais e de informações, tais como: redes de transportes (rodovias, ferrovias, hidrovias etc.) e as redes de comunicação e informação (infovias, internet, sistemas de comunicação via satélite, entre outros). A segunda é compreendida como redes de serviços ou de organização, que são determinadas pela organização de pontos e de agentes econômicos no espaço, de forma que as redes são influenciadas pelas articulações políticas e sociais no território.

Nas concepções de Pons e Reynés (2004), a infraestrutura de transporte aparece como suporte das regiões econômicas, nas quais estabelece organizações espaciais que se desenvolvem mediante as redes de transportes, que são responsáveis pelos fluxos de mercadorias, pessoas, capital e informação, promovendo a interligação espacial entre os centros de origem e de destino dos fluxos. Os autores supracitados ainda destacam que a infraestrutura de transporte é a mais importante para geração de fluxos econômicos, pois ela tem a capacidade de criar, reorientar e transformar as dinâmicas espaciais nos centros econômicos.

As redes de transportes se apresentam como elemento crucial na organização territorial das atividades agroindustriais. Bernardes e Ferreira (2013) ressaltam que a implantação das redes de transportes em novos territórios promove o dinamismo local e regional de novos eixos produtivos, também dos eixos já consolidados. Pereira (2015) define as redes de transportes como sendo um conjunto de infraestrutura viária que são estruturadas e organizadas espacialmente, conectando os fluxos de cargas e de passageiros em pontos de origem e de destino, no espaço geográfico.

As redes de transportes constituem um sistema "arterial", formado por ligações por meio de pontos (nós) que formam as instalações viárias (hidrovias, ferrovias, rodovias, vias marítimas, vias aéreas etc.). Na estrutura das redes, os nós são formados por terminais de transportes para cargas e/ou passageiros. Eles geralmente estão localizados nas cidades e em áreas rurais, a fim de conectar duas ou mais rotas por meio de estradas, trilhos e tubos. As redes de transportes podem ser operacionalizadas pelo poder público ou pela iniciativa privada. A articulação e operacionalização dos fluxos ocorrem por meio da implantação da intermodalidade e/ou multimodalidade. Os modais de transportes, os quais dão vida às redes, encontram-se divididos em: rodoviário, ferroviário, hidroviário (cabotagem), lacustre, 
marítimo, dutoviário (oleoduto, gasoduto e mineroduto) aeroviário e inter/multimodal (PEREIRA, 2015).

$\mathrm{Na}$ composição das matrizes de transportes no Brasil, também em Minas Gerais, observa-se que a rede ferroviária se concentra, principalmente, na movimentação de produtos de baixo valor agregado, cujo custo do frete corresponde a uma significativa parcela do preço final do produto. As principais mercadorias movimentadas pela modalidade ferroviária são os produtos minerais, produtos agrícolas, os combustíveis líquidos e demais produtos semi-industrializados e manufaturados (CNT, 2013). Segundo a Agência Nacional de Transportes Terrestres (ANTT), o Brasil possui uma malha ferroviária com extensão de 30.576 quilômetros (ANTT, 2019). Só o estado de Minas Gerais apresenta $17 \%$ de toda a malha ferroviária do país, sendo um importante corredor de escoamento de commodities agrícolas (ANTT, 2019). Em razão de o modal ferroviário oferecer pouca flexibilidade para os serviços de porta a porta, o transporte de grãos em Minas Gerais é feito de maneira intermodal, principalmente, para minimizar os custos operacionais e os gargalos logísticos.

Em Minas Gerais, a malha rodoviária é distribuída em rodovias federais, estaduais, municipais e com pedágios, principalmente a rede constituída por rodovias pavimentadas; desconsiderando a malha municipal de $240.572 \mathrm{~km}$, a grande maioria não é pavimentada. Na distribuição da malha total rodoviária mineira, a maior parcela da rede é estadual (71\%), sendo administrada pelo Estado e pela iniciativa privada. Somente o Departamento de Edificações e Estradas de Rodagens de Minas Gerais (DEER/MG) administra 56\% das rodovias pavimentadas e $13 \%$ das rodovias não pavimentadas da malha total mineira. Esse órgão público é responsável pela gestão de mais da metade da rede rodoviária de Minas (69\%). Já o Departamento Nacional de Infraestrutura de Transporte (DNIT) gerencia 18\% da rede mineira, sendo $16 \%$ vias pavimentadas e $02 \%$ vias não pavimentadas. O restante da malha total mineira (13\%) está distribuída entre rodovias federais, estaduais e municipais, que está sob a gestão de empresas concessionárias que são responsáveis pela utilização geral das vias por meio da cobrança de pedágios (Vide Tabela 01).

Tabela 01 - Malha rodoviária de Minas Gerais (quilômetros)

\begin{tabular}{c|c|c|c|c|c}
\hline $\begin{array}{c}\text { Rede } \\
\text { Federal }\end{array}$ & $\begin{array}{c}\text { Responsável } \\
\text { pela via }\end{array}$ & $\begin{array}{c}\text { Via } \\
\text { Pavimentada } \\
\mathbf{( K m )}\end{array}$ & $\begin{array}{c}\text { Via não } \\
\text { Pavimentada } \\
\mathbf{( K m )}\end{array}$ & $\begin{array}{c}\text { Total } \\
\mathbf{( K m )}\end{array}$ & $\begin{array}{c}\text { Total } \\
\mathbf{( \% )}\end{array}$ \\
\cline { 2 - 6 } & $\begin{array}{c}\text { Concessionárias } \\
\text { federais }\end{array}$ & $3.175,4$ & Não houve & $3.175,4$ & 8,0 \\
\cline { 2 - 6 } Estadual & DNIT & $6.061,2$ & 576,8 & $6.638,0$ & 18,0 \\
\cline { 2 - 6 } & $\begin{array}{c}\text { Concessionárias } \\
\text { estaduais }\end{array}$ & 760,4 & Não houve & 760,4 & 2,0 \\
\hline $\begin{array}{c}\text { Rede } \\
\text { Municipal }\end{array}$ & $\begin{array}{c}\text { Concessionárias } \\
\text { Municipais }\end{array}$ & $1.068,7$ & 17,7 & $1.086,4$ & 3,0 \\
\hline \multicolumn{2}{c|}{ Total } & $31.944,2$ & $5.408,4$ & $37.352,6$ & 100,0 \\
\hline
\end{tabular}

Fonte: Departamento de Edificações e Estradas de Rodagens de Minas Gerais - DEER/MG, 2019. Nota: Desconsideraram-se os 240. $572 \mathrm{~km}$ de malha municipal.

Vale ressaltar que grande parte das rodovias federais e estaduais ainda está sob a gestão do Estado, que muitas vezes não possui recursos para investir nas vias. O Estado tem buscado passar para a iniciativa privada o direito de gestão das vias públicas para que a população tenha rodovias com melhor trafegabilidade. No entanto, a iniciativa privada tem buscado administrar apenas rodovias capazes de oferecer grandes fluxos de pessoas e cargas. 
No território mineiro, as modalidades de transportes se integram por meio da intermodalidade e/ou multimodalidade que abarcam o escoamento de commodities agrícolas. Nas redes de escoamento de produção e comercialização de grãos, os serviços de transportes interconectam com a infraestrutura do país. Nas exportações de grãos em Minas Gerais, como o café, a logística de transportes é articulada por meio das redes de transportes (rodoviária, ferroviária e rodoferroviária).

$\mathrm{Na}$ organização espacial da rede rodoviária de Minas Gerais, a logística de escoamento se estrutura em rodovias pavimentadas de pista simples e/ou duplicadas, principalmente a BR 050; BR 365; BR 040; BR 262; BR 381, entre outras. Essas rodovias constituem os principais corredores logísticos estratégicos para a exportação do setor de grãos no território mineiro. Já estradas não pavimentadas, nas áreas rurais, são utilizadas mais para transportar os produtos das fazendas para os armazéns/silos e/ou unidades processadoras. Sendo que a falta de pavimentação das estradas causa transtornos para os empresários e produtores do setor de grãos. Além das rodovias e estradas, Minas Gerais também dispõe da rede de transporte intermodal, composta por três terminais, sendo eles: o Terminal Integrador de Pirapora, o de Araguari e o de Uberaba. Esses Terminais Intermodais, são operacionalizados pela empresa privada de base ferroviária, que é a Valor da Logística Integrada (VLI), que transporta cargas de produtos agrícolas até os portos (Porto de Tubarão e Porto de Santos). Essas informações são mostradas no Mapa 03.

Mapa 03 - Estado de Minas Gerais: infraestrutura de transportes do setor agroindustrial

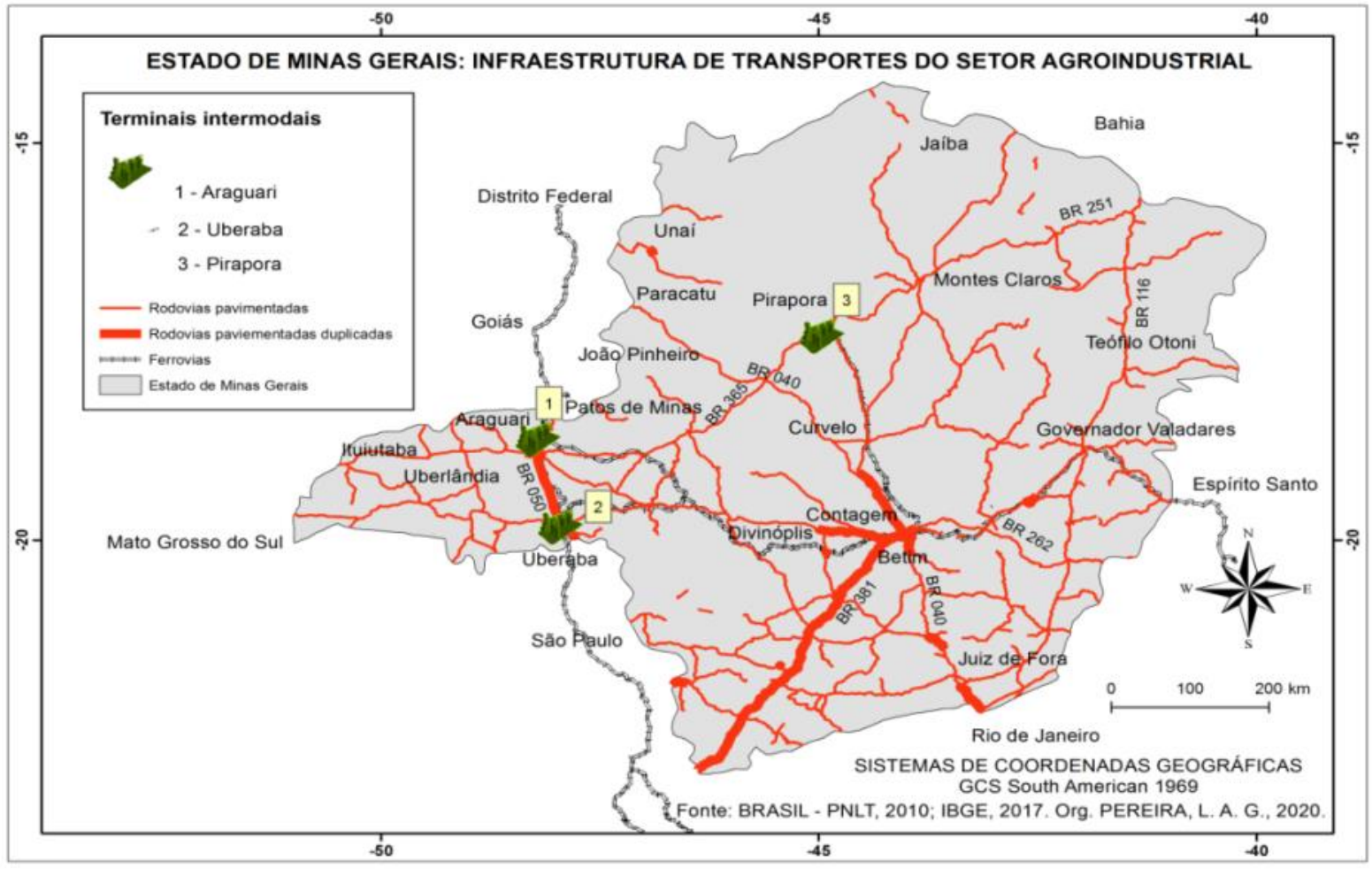

Fonte: BRASIL - PNLT, 2010; IBGE, 2017. Org. PEREIRA, L. A. G., 2020.

No território mineiro, as corporações utilizaram as modalidades de transportes rodoviário, ferroviário e rodoferroviário no escoamento de commodities agrícolas destinadas ao comércio exterior. A interconexão da logística nacional com a internacional é de suma importância na organização da produção e da distribuição do café em mercados globais, uma vez que os recintos alfandegados (portos, aeroportos e pontos de fronteiras) assumem as funções de prestar serviços logísticos, que viabilizem as redes de interações socioespaciais Patrick Pereira de Jesus e Luiz Andrei Gonçalves Pereira. Logística de transportes e exportações de café no estado de Minas Gerais, Brasil Brazilian Geographical Journal: Geosciences and Humanities research medium,

Ituiutaba, v. 11, n. 1, p. 214-239, jan./jul. 2020. 
dos negócios realizados pelos agentes econômicos. Nesse contexto, na seção seguinte, discute-se a logística de transportes aplicada à exportação de café em Minas Gerais.

\section{Comercialização e inserção de café originário de Minas Gerais nos mercados globais: a logística de exportações de café}

Na organização espacial das redes de transportes, na prestação de serviços inter e intraempresa, a parte operacional da logística funciona por meio da interação sincronizada entre a infraestrutura de transportes, terminais de transportes, fluxos de informações e demais serviços logísticos, articulando fornecedores, produtores, prestadores de serviços, comerciantes e consumidores no espaço geográfico local, regional, nacional e global (PEREIRA; FERREIRA, 2013).

Após a concretização da comercialização, Pereira e Ferreira (2013) pontuam que os produtos precisam ser entregues aos compradores atacadistas e varejistas, sendo que a distribuição necessita da infraestrutura de transportes e dos serviços logísticos para interligar produtores, distribuidores e consumidores em diferentes locais do mundo. A logística internacional tem como função gerenciar e coordenar os fluxos físicos para que o cliente possa ter um serviço de qualidade, no menor tempo e com baixo custo. No entanto, isso não se torna uma tarefa fácil devido às variáveis de eficiência de cada país (SILVA et. al, 2010). Muito embora a logística englobe manutenção de estoques e processamentos de pedidos e marketing, o transporte é a atividade mais importante conforme apontado por Ballou (1993). Ele engloba variáveis importantes e que podem comprometer os níveis de serviços, gerando assim altos custos operacionais. Por isso é importante analisar os sistemas de transportes do Brasil e de Minas Gerais utilizados na logística internacional.

No Brasil e em Minas Gerais, as modalidades de transportes utilizadas no transporte de commodities agrícolas, destinadas ao comércio exterior, se estruturam no modal rodoviário, ferroviário e hidroviário, marítimo e inter/multimodal. Nesse contexto, a prestação de serviços nesses modais articula os fluxos de mercadorias na transposição no espaço geográfico (PEREIRA, 2015). Nos fluxos de commodities voltados para o mercado exterior, deve-se levar em consideração a escolha das modalidades. A escolha de qualquer uma delas deve considerar não só o tempo a ser gasto com o transporte, mas também o tipo de mercadoria a ser transportada. Cada modalidade de transportes oferece um número de vantagem e desvantagens para o escoamento de commodities agrícolas (CAIXETA-FILHO, 2001; CAIXETA-FILHO, 2010).

No comércio internacional, o modal rodoviário é mais utilizado para transportes nas regiões do Mercosul, compreendendo os países vizinhos do Brasil, como Argentina, Paraguai, Uruguai e Chile. Nele, pode-se movimentar uma diversidade de mercadorias para qualquer destino de porta a porta. Em suma, pode-se dizer que ele é recomendado para o acesso a países fronteiriços, oferecendo assim mais flexibilidade na movimentação. $\mathrm{O}$ modal ferroviário é mais utilizado para transportar cargas pesadas, em grandes quantidades e com baixo valor agregado, ou para destinos com malha rodoviária. As principais cargas que são escoadas por ferrovia são as do setor de mineração e do setor agrícola, que correspondem a aproximadamente $85 \%$ e $10 \%$ respectivamente. Diferente do modal rodoviário que possui flexibilidade de entregar de porta a porta, o ferroviário oferece pouca flexibilidade. O modal aéreo é utilizado para transportar cargas de alto valor agregado, leves e de baixo peso e dimensão, como joias e amostras de produtos. Embora ofereça viagens de curta duração, favorecendo a preservação da qualidade da mercadoria, é pouco utilizado devido aos seus altos custos. Já o transporte marítimo é utilizado para transportar cargas pesadas em grandes quantidades e com baixo valor agregado, ou para destino com e sem acessos terrestres. Ele é o modal mais utilizado no transporte internacional (CAIXETA-FILHO, 2010). 
Na Geografia Econômica, as redes de transportes ganham notoriedade por intermédio da aplicação das tecnologias de informação geográfica, servindo de suporte na tomada de decisões no segmento empresarial. Sendo assim, nos últimos anos, o Sistema de Informação Geográfica (SIG) tem sido considerado uma excelente tecnologia na Geografia dos Transportes, uma vez que o SIG é um instrumento metodológico que permite fazer a análise das redes, bem como questões voltadas para os impactos ambientais, a localização, os acidentes etc. (PONS; REYNÉS, 2004). Diante disso, para compreender a operacionalização e organização da logística de transportes nos fluxos comerciais de café em Minas Gerais, foram elaborados os mapas temáticos para apresentar os fluxos dos produtos por recintos alfandegados e matriz de transporte internacional, assim como suas comercializações por meio dos principais mercados globais que compram os produtos produzidos no território mineiro.

Nos fluxos das exportações de café, principal grão produzido e vendido pelas empresas localizadas em Minas Gerais, utilizou-se somente o modal rodoviário para movimentar o produto até os portos, aeroportos, pontos de fronteira e portos secos. Na distribuição dos fluxos das exportações de café, o Porto de Santos concentrou 83\% dos fluxos monetários e $91,2 \%$ dos fluxos em quilograma; seguido do Porto do Rio de Janeiro que recebeu $09 \%$ dos fluxos financeiros e $05 \%$ dos fluxos em peso; do Porto de Vitória com 04\% dos fluxos financeiros e 2,4\% dos fluxos em quantidade quilograma. Os demais portos juntos tiveram pouca concentração dos fluxos do produto, pois todos representaram menos de $01 \%$ dos saldos monetários e da quantidade em quilo. Já os demais recintos alfandegados (pontos de fronteira, aeroportos, portos secos e correios) também concentraram menos de $01 \%$ dos fluxos financeiros e em quilograma. Consequentemente, pode-se afirmar que aproximadamente $99 \%$ das exportações de café é realizado por meio do transporte marítimo, que é adequado para o escoamento desse tipo de produto. Essas informações podem ser vistas no mapa 04 e no mapa 05.

Chegando aos recintos alfandegados, o café exportado por empresas localizadas no território mineiro é destinado a diversos mercados internacionais, que aqui foram agrupados por países em blocos econômicos, destacando-se os blocos: Cooperação Econômica da Ásia e do Pacífico ${ }^{2}$ (APEC), União Europeia3 (UE), Mercado Comum do Sul 4 (MERCOSUL 5) e Tratado Norte-Americano de Livre Comércio5 (NAFTA), entre outros blocos.

Nos fluxos das exportações de café, no período de 1997 a 2018, destacou-se a União Europeia que comprou $59 \%$ dos valores financeiros e $60 \%$ da quantidade em quilo, enquanto o NAFTA adquiriu 19\% dos valores em dinheiro e $18 \%$ do peso/volume. Em seguida, a APEC (excluso o NAFTA), que comprou 15\% em valor monetário e $15 \%$ da quantidade em quilo. Os demais blocos econômicos juntos representaram menos de 07\% dos fluxos financeiros e em peso/volume. As informações acerca das exportações de café em Minas Gerais, por mercados organizados em blocos econômicos, podem ser visualizadas no mapa 06.

2 Cooperação da Ásia e do Pacífico - APEC - Austrália, Brunei Darussalam, Canadá, Chile, China, Indonésia, Japão, Coreia do Sul, Malásia, México, Nova Zelândia, Papua Nova-Guiné, Peru, Filipinas, Rússia, Singapura, Tailândia, Vietnã e Estados Unidos, além de Taiwan e Hong Kong (China).

3 União Europeia (UE) - Alemanha, Áustria, Bélgica, Bulgária, Chipre, Croácia, Dinamarca, Eslováquia, Eslovênia, Espanha, Estônia, Finlândia, França, Grécia, Hungria, Irlanda, Itália, Letônia, Lituânia, Luxemburgo, Malta, Países Baixos (Holanda), Polônia, Portugal, Reino Unido, República Tcheca, Romênia e Suécia.

4 Mercado Comum do Sul (MERCOSUL) - Brasil, Argentina, Uruguai, Paraguai e Venezuela

5 Tratado Norte-Americano de Livre Comércio (NAFTA) - Estados Unidos, Canadá e México. 
Mapa 04 - Exportações de café em grão no Estado de Minas Gerais: fluxos por recintos alfandegados, no período de 1997 a 2018 (US\$/FOB)

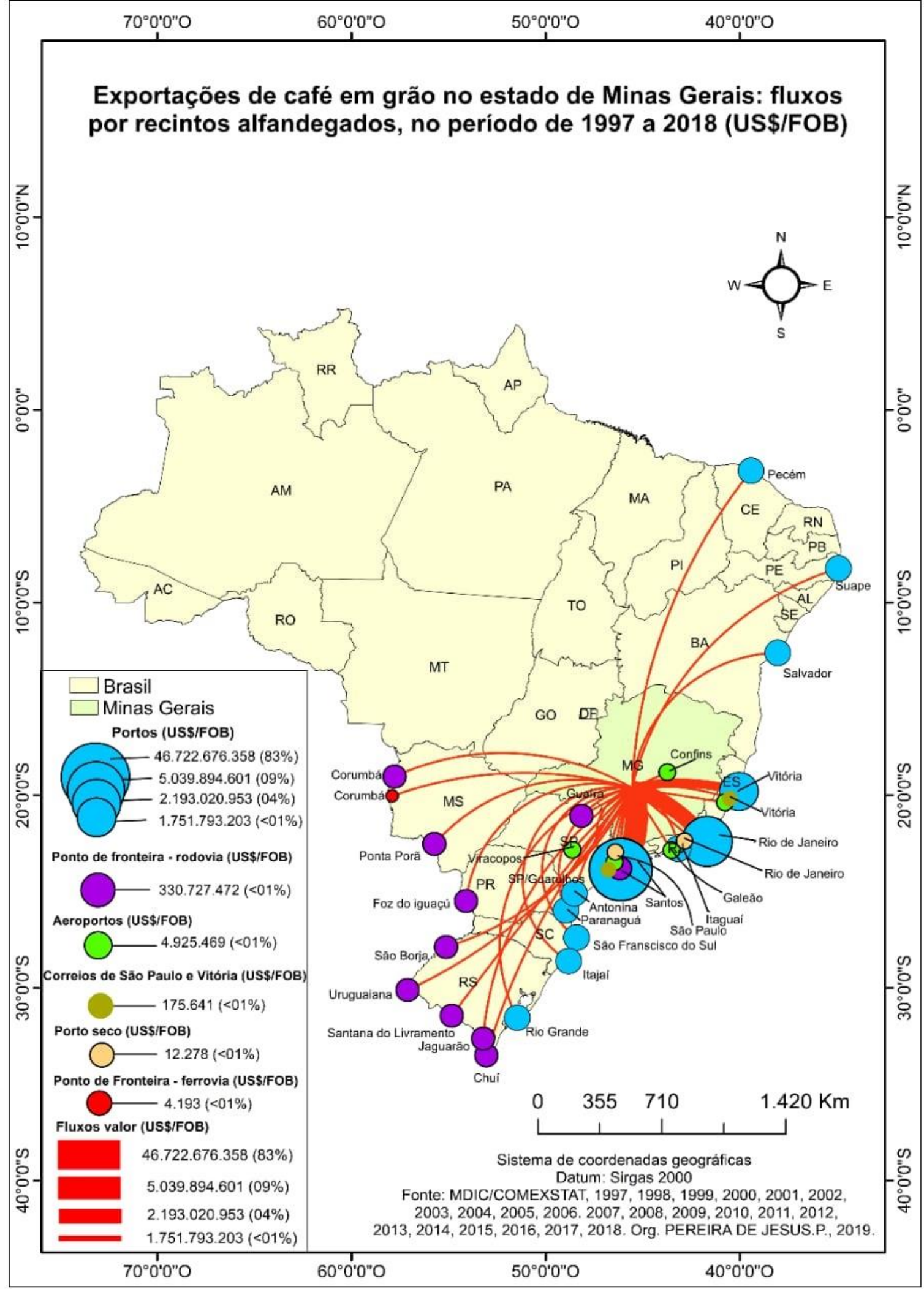

Fonte: MDIC/COMEXSTAT, 1997; 1998; 1999; 2000; 2001; 2002; 2003; 2004; 2005; 2006; 2007; 2008; 2009; 2010; 2011; 2012; 2013; 2014; 2015; 2016; 2017; 2018. Org. PEREIRA DE JESUS, P., 2020. Patrick Pereira de Jesus e Luiz Andrei Gonçalves Pereira. Logística de transportes e exportações de café no estado de Minas Gerais, Brasil Brazilian Geographical Journal: Geosciences and Humanities research medium, Ituiutaba, v. 11, n. 1, p. 214-239, jan./jul. 2020. 
Mapa 05 - Exportações de café em grão no Estado de Minas Gerais: fluxos por recintos alfandegados, no período de 1997 a $2018(\mathrm{~kg})$

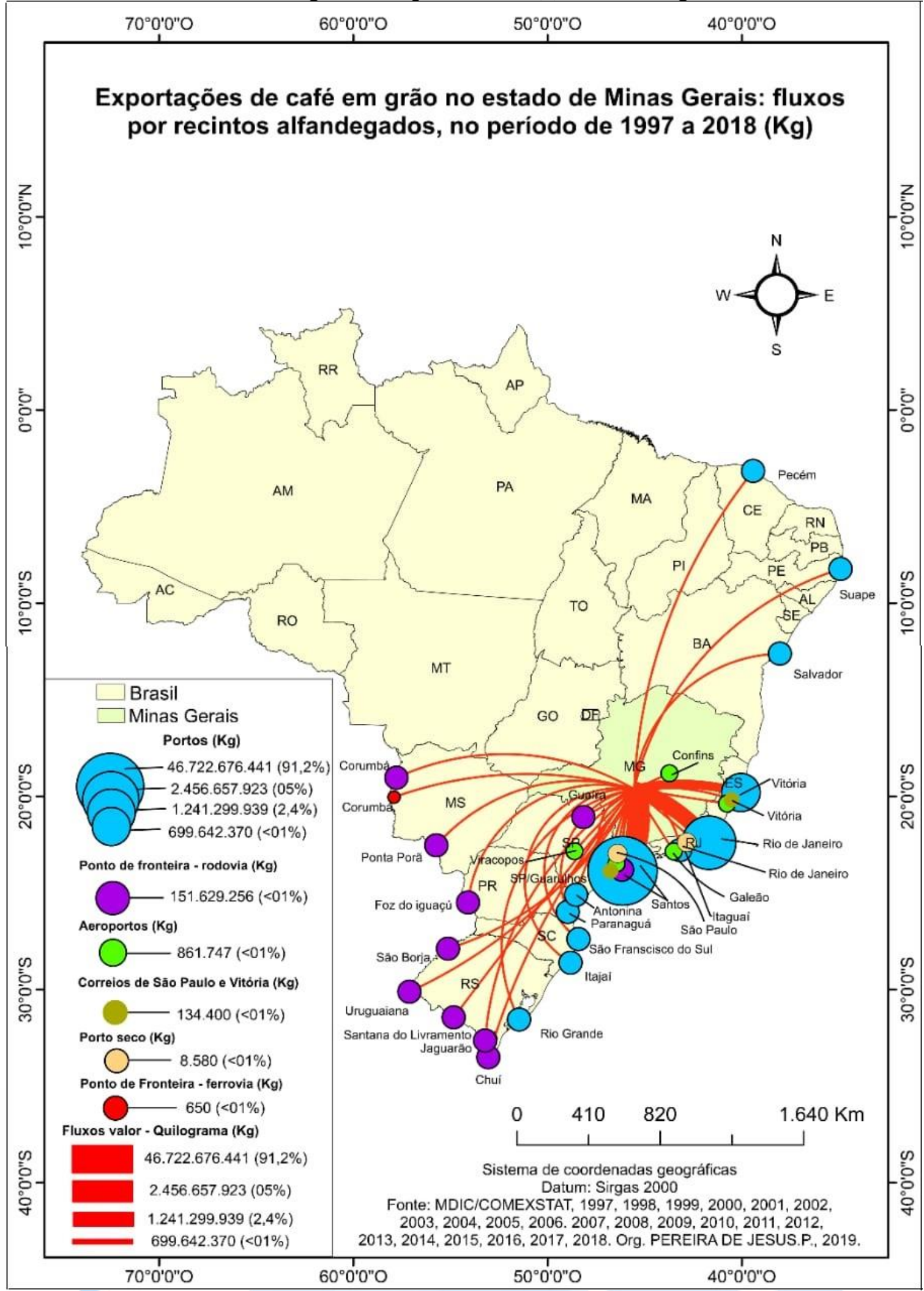

Fonte: MDIC/COMEXSTAT, 1997; 1998; 1999; 2000; 2001; 2002; 2003; 2004; 2005; 2006; 2007; 2008; 2009; 2010; 2011; 2012; 2013; 2014; 2015; 2016; 2017; 2018. Org. PEREIRA DE JESUS, P., 2020. Patrick Pereira de Jesus e Luiz Andrei Gonçalves Pereira. Logística de transportes e exportações de café no estado de Minas Gerais, Brasil Brazilian Geographical Journal: Geosciences and Humanities research medium, Ituiutaba, v. 11, n. 1, p. 214-239, jan./jul. 2020. 
Mapa 06 - Exportações de Café em Grão no Estado de Minas Gerais: Principais Mercados Internacionais por Blocos Econômicos (1997-2018)

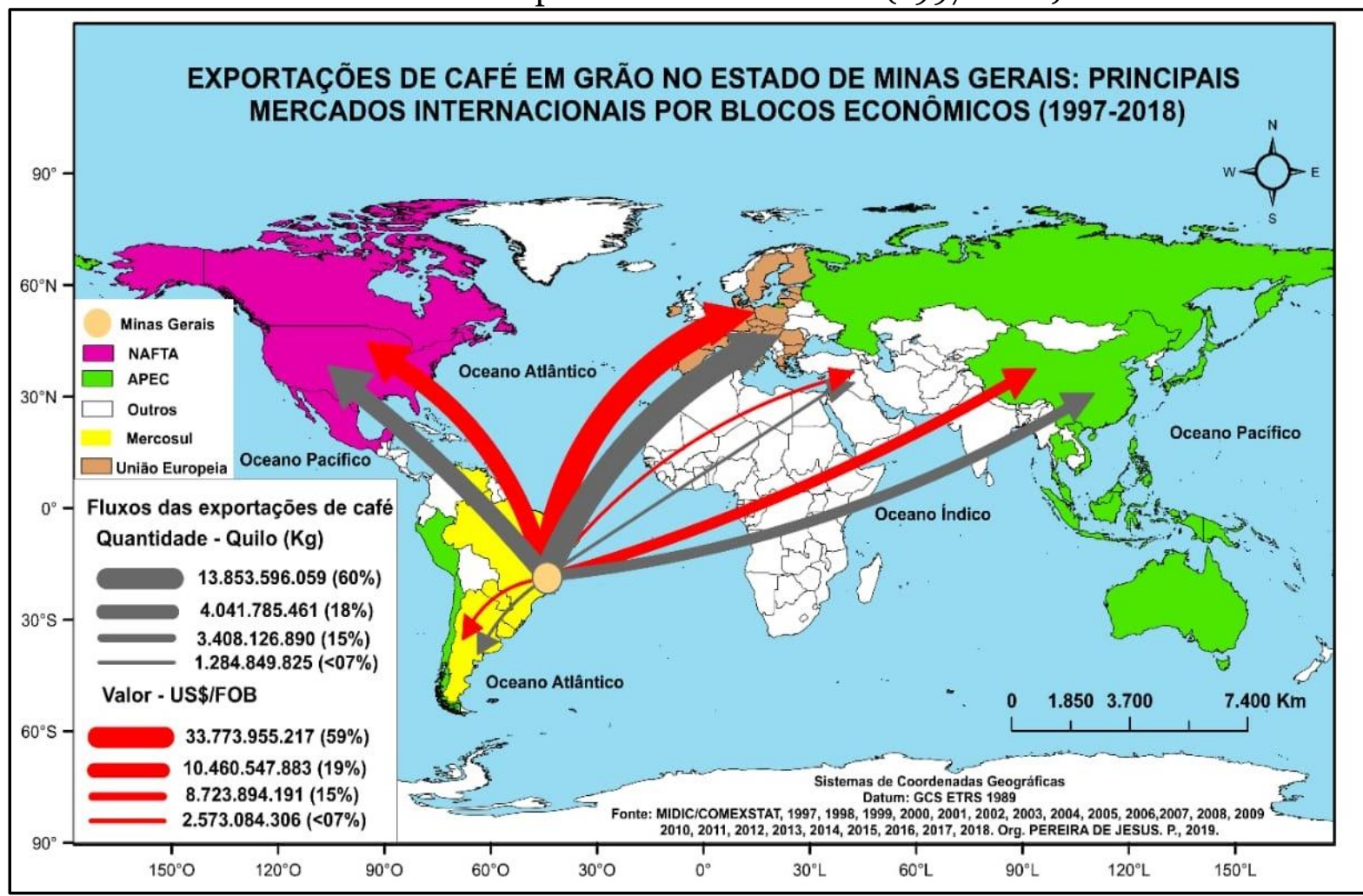

Fonte: MDIC/COMEXSTAT, 1997; 1998; 1999; 2000; 2001; 2002; 2003; 2004; 2005; 2006; 2007; 2008; 2009; 2010; 2011; 2012; 2013; 2014; 2015; 2016; 2017; 2018. Org. PEREIRA DE JESUS, P., 2020.

No mercado da União Europeia, maior comprador do café mineiro, os países que destacaram-se nas compras da mercadoria foram a Alemanha, Itália, Bélgica, França, Espanha, Suécia, Reino Unido, Finlândia, Holanda e Grécia, concentrando $96 \%$ das importações do produto em valor monetário e 93\% dos valores em quilograma. Essas informações podem ser vistas na Tabela 02.

Tabela 02 - Exportações de café em grão em Minas Gerais: fluxos do produto para o mercado União Europeia, no período acumulado de 1997 a 2018

\begin{tabular}{|c|c|c|c|c|}
\hline Países & Valor US\$ (FOB) & \% & Quilograma (Kg) & $\%$ \\
\hline Alemanha & 12.617 .385 .213 & 37,0 & 5.180 .732 .231 & 37,0 \\
\hline Itália & 6.006 .701 .792 & 18,0 & 2.357 .562 .320 & 17,0 \\
\hline Bélgica & 4.254 .849 .265 & 13,0 & 1.548 .020 .354 & 11,0 \\
\hline França & 1.611 .420 .737 & 8,0 & 716.570 .901 & 5,0 \\
\hline Espanha & 1.617 .103 .578 & 5,0 & 672.058 .368 & 5,0 \\
\hline Suécia & 1.499 .033 .433 & 4,0 & 646.504 .048 & 5,0 \\
\hline Reino Unido & 1.019 .882 .425 & 3,0 & 35.5326 .911 & 3,0 \\
\hline Finlândia & 1.118 .042 .494 & 3,0 & 446.716 .498 & 3,0 \\
\hline Países Baixos (Holanda) & 1.016 .720 .974 & 3,0 & 446.965 .119 & 3,0 \\
\hline Grécia & 676.287 .921 & 2,0 & 527.389 .076 & 4,0 \\
\hline Outros (demais países) & 23.365 .27 .385 & 4,0 & 955.750 .233 & 7,0 \\
\hline Total & 33.773 .955 .217 & 100,0 & 13.853 .596 .059 & 100,0 \\
\hline
\end{tabular}

Fonte: MDIC; COMEX STAT, 1997, 1998, 1999, 2000, 2001, 2002, 2003, 2004, 2005, 2006, 2007, 2008, 2009, 2010, 2011, 2012, 2013, 2014, 2015, 2016, 2017, 2018. Org. PEREIRA DE JESUS, P., 2020.

Patrick Pereira de Jesus e Luiz Andrei Gonçalves Pereira. Logística de transportes e exportações de café no estado de Minas Gerais, Brasil Brazilian Geographical Journal: Geosciences and Humanities research medium.

Ituiutaba, v. 11, n. 1, p. 214-239, jan./jul. 2020.

Página | 233 
É importante frisar que, esses países, principalmente a Alemanha, Itália, Bélgica e França, compram o café a granel dos empresários localizados em Minas Gerais e agregam valor ao produto. Ou seja, no mercado de grãos, os países importadores compram o produto primário para serem processados e vendidos em todo o mundo, bem como, para atender o mercado doméstico.

No escoamento de café, as principais rodovias das maiores regiões produtoras (Sul/Sudoeste de Minas, Triângulo Mineiro/Alto Paranaíba e Zona da Mata) são: a BR 040, a BR 382 e a BR 050. É importante ressaltar que o produto é escoado apenas por modal rodoviário das unidades produção, armazenagem e/ou processamento até as unidades de exportação, principalmente nos Portos de Santos e do Rio de Janeiro. Essa particularidade no escoamento do produto, ou seja, do não uso de intermodalidade, tem como principal fator determinante a infraestrutura de transporte das regiões.

Segundo Machado (2018), na principal Mesorregião produtora (Sul/Sudoeste de Minas) encontram-se os principais produtores do país, as maiores cooperativas, torrefadoras e o principal Porto Seco do país (Varginha), além de ficar próximo dos principais portos de exportação do produto (Santos e Rio Janeiro). Como a malha ferroviária é curta, em relação à rodoviária, é necessário que haja investimentos para levar ferrovias até os portos, como no de Varginha, em que os empresários preferem utilizar o modal rodoviário. Contudo, a precariedade da infraestrutura rodoviária, bem como as longas distâncias percorridas no escoamento das mesorregiões produtoras elevam os preços no mercado externo. Assim, é necessário que melhorem a infraestrutura das regiões produtoras, principalmente com investimentos na rede ferroviária.

\section{Considerações finais}

No comércio internacional do agronegócio a oferta e a demanda de commodities agrícolas têm sido um fator determinante para investimentos em logística, principalmente na área de transportes. É indiscutível a importância do agronegócio à economia do país e de Minas Gerais, assim como a posição que ele ganhou no cenário do comércio internacional. Nas exportações de Minas Gerais, os agentes do segmento de grãos escolheram as redes de infraestrutura e serviços de transportes mais adequados para o escoamento de café.

O escoamento do produto das unidades produtoras/processadoras se deu pela modalidade rodoviária. Embora o transporte rodoviário não seja adequado para escoar grãos por longas distâncias, a extensa malha rodoviária e a precariedade da rede ferroviária têm influenciado o uso desse modal (rodoviário) do local de produção/armazenagem até os recintos alfandegados para todas as cargas de café exportadas.

No transporte internacional, o modal marítimo concentrou aproximadamente $99 \%$ das exportações de café. Ao estabelecer estratégias de conexões com os mercados, os empresários situados em Minas Gerais - a maioria deles - escolheram os terminais portuários. Dessa forma, os portos de Santos e Rio de Janeiro foram os principais recintos alfandegados que receberam maior concentração dos fluxos de café exportados, correspondendo a mais de $90 \%$ dos fluxos financeiros e em quantidade/quilo. Isso ocorreu devido à oferta de serviços logísticos especializados em embarques de café que se desenvolveram nos portos da região Sudeste.

Considerando os mercados internacionais das exportações da cafeicultura no Estado de Minas Gerais, destacam-se os mercados europeus, norte-americanos, asiáticos, entre outros. Sendo importante destacar que os mercados da União Europeia compraram dos exportadores mineiros cerca de $59 \%$ dos valores financeiros e $60 \%$ da quantidade em quilogramas de café.

Em um cenário internacional de incertezas políticas e econômicas, as exportações mostraram que o setor de café de Minas Gerais é competitivo. Diante dos gargalos logísticos, 
foram escolhidas as melhores alternativas para escoamento das exportações do produto. Contudo, faz-se necessário que os empresários mineiros, em parceria com o Estado, (1) desenvolvam estratégias de investimentos para melhorar a infraestrutura e os serviços logísticos, com o objetivo distribuir de maneira mais adequada as matrizes de transportes para as exportações da mercadoria; (2) invistam no transporte intermodal e em estruturas de processamento/armazenagem. Na escala nacional, é necessário que os portos marítimos se especializem cada vez mais para melhorar os serviços de transbordo. Por meio dessas medidas, os exportadores irão agregar valor ao café, oferecendo de forma competitiva e otimizada na rede de distribuição do café em mercados globais, atendendo assim, os requisitos dos importadores internacionais. Quanto às incertezas políticas e econômicas, fazse necessário que os agentes econômicos mineiros promovam negociações entre empresas, enquanto o Estado brasileiro desenvolva as negociações que resultem em celebração de acordos internacionais para expansão das exportações.

É importante frisar, que o transporte intermodal é o mais adequado para o transporte de cargas agrícolas, principalmente em regiões com grande extensão territorial, como é o Brasil e de Minas Gerais. Dessa forma, os investimentos na infraestrutura de transportes devem abranger as modalidades como um todo, buscando ajustar e/ou corrigir as distorções das matrizes de transportes atuais. Além do transporte intermodal, também é necessário investimento na infraestrutura de armazenagem (armazéns e silos) e portos secos em larga escala e em serviços aduaneiros e de fiscalização de cargas etc. Todas essas medidas permitirão uma melhor eficiência e eficácia das exportações mineiras de produtos agrícolas e, consequentemente, a redução de custos para melhor competitividade das empresas de grãos, principalmente o setor de café.

\section{Agradecimentos}

À Fundação de Apoio à Pesquisa do Estado de Minas Gerais - FAPEMIG, pelo financiamento do projeto, ao qual encontra-se vinculada esta pesquisa.

\section{Referências}

AGÊNCIA NACIONAL DE TRANSPORTES TERRESTRES - ANTT. Ferrovias: anuário estatístico. Brasília: ANTT, 2019.

ALBUQUERQUe, R. H. P. L. de; GARCIA, Ronaldo C. Política científica e tecnológica para o setor agroindustrial: reflexões sobre a experiência brasileira. Campinas: Núcleo de Política Científica e Tecnológica - NPCT - UNICAMP, 1988.

BALLOU, R. H. Logística empresarial: transportes, administração de materiais e distribuição física. Tradução de Hugo T. Y. Yoshizaki. São Paulo: Atlas, 1993. 388 p.

BARAT, J. Globalização, logística e transportes aéreo. São Paulo: Editora Senac, 2012. $269 \mathrm{p}$.

BASTOS, S. Q. A; GOMES, J. E. Dinâmica da agricultura no estado de Minas Gerais. Ruris, [S./l.], $\quad$ v. $\quad 5, \quad$ n. 2011.2 Disponível <https://www.ifch.unicamp.br/ojs/index.php/ruris/article/view/1463>. Acesso em: 25 jun. 2019.

BERNARDES, F. F; FERREIRA, W. R. A logística em transporte no Triângulo Mineiro e Alto Paranaíba: operacionalizando os sistemas agrícolas. OBSERVATORIUM: Revista 
Eletrônica de Geografia, Uberlândia, v.5, n.13, p. 101-124, jun. 2013. Disponível em:< http://www.observatorium.ig.ufu.br/pdfs/5edicao/n13/o6.pdf>. Acesso em: 02 jun. 2019.

CAIXETA-FILHO, J. V. Introdução: a competitividade do transporte no agribusiness brasileiro. In: CAIXEITA-FILHO, J. V.; GAMEIRO, A. H. (Org.). Transporte e logística em sistemas agroindustriais. São Paulo: Atlas, 2001.

CAIXETA-FILHO, J. V. Logística para a agricultura brasileira. Revista Brasileira de Comércio Exterior, [S./l.], v. 103, p. 18-30, 2010. Disponível em: $<$ http://esalqlog.esalq.usp.br/en/caixeta-filho-j-v-logistica-para-a-agricultura-brasileirarevista-brasileira-de-comercio-exterior-v-103-p-18-30-2010> Acesso em: 10 jul. 2019.

CAIXETA-FILHO, V. J.; MARTINS S. R. Gestão Logística do Transporte de Cargas. São Paulo: Atlas S.A, 2007.

CLEPS JUNIOR, J. Dinâmica e estratégias do setor agroindustrial no cerrado: o caso do Triângulo Mineiro. 1998. 291 f. Tese (Doutorado em Organização do Espaço), Instituto de Geociências e Ciências Exatas, UNESP, Rio Claro, 1998.

CASTILLO, R. Agronegócio e Logística em Áreas de Cerrado: expressão da agricultura científica globalizada. Revista da ANPEGE, [S./l.], v. 3, p. 33 - 43, 2007. Disponível em:< http://ojs.ufgd.edu.br/index.php/anpege/article/view/6604>. Acesso em: 05 mar. 2019.

CASTILLO, R. Dinâmica regional e globalização: espaços competitivos agrícolas no território brasileiro: Mercator, Fortaleza, v. 9, n. 18, p. 16-26, 2010. Disponível em: <http://www.mercator.ufc.br/index.php/mercator/article/viewArticle/330>. Acesso em: 12 mar. 2016.

CASTILLO, R. Transporte e logística de granéis sólidos agrícolas: componentes estruturais do novo sistema de movimentos do território brasileiro. Investigaciones Geográficas, México, n. 55, p. 79-96, 2004. Disponível em: <http://www.scielo.org.mx/pdf/igeo/n55/n55a6.pdf>. Acesso em: 01 mar. 2019.

CASTILLO, R. Exportar alimentos é a saída para o Brasil? O caso do complexo soja. In: E. Silvestre Albuquerque (org.). Que país é esse? Pensando o Brasil contemporâneo. São Paulo: Ed. Globo, 2005.

COMPANHIA NACIONAL DE ABASTECIMENTO - CONAB. Produção de café deve ser a maior da história com quase 60 milhões de sacas. 2018. Disponível em:< https://www.conab.gov.br/ultimas-noticias/2512-producao-de-cafe-deve-ser-a-maior-dahistoria-com-quase-60-milhoes-de-sacas>. Acesso em: 02 jun. 2019.

CONFEDERAÇÃO NACIONAL DO TRANSPORTE - CNT. O Sistema ferroviário brasileiro. Brasília: CNT, 2013, 58 p.

CUNHA, R. C. Estruturas, estratégias de mercado e comercialização e fluxos de distribuição da soja no sul do Maranhão. XI - Encontro Nacional da Anpege, 2015.

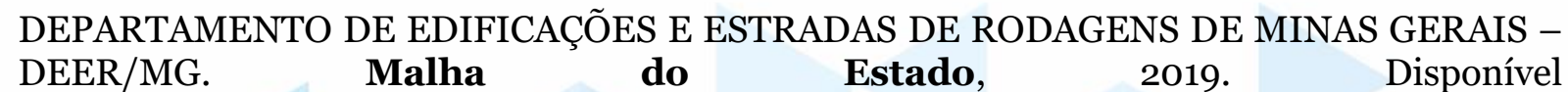
em:<http://www.deer.mg.gov.br/transportes/rodovias/16-transportes/738-malha-doestado >. Acesso em: 20 dez. 2019.

FAJARDO, S. A ação territorial corporativa no espaço rural. In: VIDEIRA, S. L.; COSTA, P. A.; FAJARDO, S. (Org.). Geografia Econômica: (re)leituras contemporâneas. Rio de Janeiro: Letra Capital, 2011. 193 p. p. 47-66. 
FAJARDO, S. Estratégias e territorialidades das cooperativas agropecuárias e das empresas globais do setor agroindustrial no Paraná. Tese (doutorado em Geografia) - Programa de Pós-graduação em Geografia, Universidade Estadual Paulista, Presidente Prudente, 2007.2 Disponível em:<http://www2.fct.unesp.br/pos/geo/dis_teses/o7/sergiofajardo.pdf > Acesso em: 20 fev. 2019.

FREDERICO, S. Expansão da fronteira agrícola e emergência de uma agricultura científica globalizada no território brasileiro. Revista Geográfica da América Central, [S./l.], v. 2, n. $47 \mathrm{E}, \quad$ p. $1-18, \quad 2011.20$ Disponível em:<https://www.revistas.una.ac.cr/index.php/geografica/article/view/2363>. Acesso em: o3 fev. 2019.

FREDERICO, S. Território e cafeicultura no Brasil: uma proposta de periodização. Geousp - Espaço e Tempo (Online), São Paulo, v. 21, n. 1, p. 73-101, abril. 2017. Disponível em:

< http://www.revistas.usp.br/geousp/article/view/98588>. Acesso em: 04 jun. 2019.

INSTITUTO BRASILEIRO DE GEOGRAFIA E ESTATÍSTICA - IBGE. Divisão do Brasil em mesorregiões e microrregiões geográficas. V. 1, Rio de Janeiro, 1990. Disponível em: $\quad<$ http://biblioteca.ibge.gov.br/visualizacao/monografias/GEBIS\%20\%20RJ/DRB/Divisao\%20regional_v01.pdf>. Acesso em: 15 jun. 2018.

INSTITUTO BRASILEIRO DE GEOGRAFIA E ESTATÍSTICA - IBGE. Censo 2o1o. Brasília: IBGE, 2010. Disponível em: <https://censo2010.ibge.gov.br/>. Acesso em: 22 jul. 2019.

INSTITUTO BRASILEIRO DE GEOGRAFIA E ESTATÍSTICA - IBGE. Bases cartográficas/Malhas digitais. Brasília: IBGE, 2015. Disponível em:

$<\quad$ https://mapas.ibge.gov.br/bases-e-referenciais/bases-cartograficas/malhasdigitais.html>. Acesso em: 12 fev. 2019.

INSTITUTO BRASILEIRO DE GEOGRAFIA E ESTATÍSTICA - IBGE. Bases cartográficas/Malhas digitais. Brasília: IBGE, 2017. Disponível em: <https://mapas.ibge.gov.br/tematicos/infra-estrutura-e-logistica>. Acesso em: 10 jul. 2019.

INSTITUTO BRASILEIRO DE GEOGRAFIA E ESTATÍSTICA - IBGE. Sidra - Produção agrícola Municipal. Brasília: IBGE, 2019. Disponível em:

< https://sidra.ibge.gov.br/tabela/5457\#resultado>. Acesso em: 12 fev. 2019.

INSTITUTO BRASILEIRO DE GEOGRAFIA E ESTATÍSTICA - IBGE. Sidra - População/ Estimativa de população. Brasília: IBGE, 2019. Disponível em:

<https://sidra.ibge.gov.br/tabela/5457\#resultado>. Acesso em: 12 fev. 2019.

LIMA, R. C. O uso corporativo do território pelo agronegócio e a questão da logística de transportes em Mato Grosso. Tese (doutorado em Geografia) - Programa de Pós-graduação em Geografia, Universidade de Brasília, 2015. Disponível em:

< http://repositorio.unb.br/handle/10482/19270>. Acesso em: 27 abr. 2019.

LOURENÇO, J. C. Logística Agroindustrial: desafios para o Brasil na primeira década do século XXI. 2009. 74 f. Monografia (Graduação em Administração), Centro de Ciências Humanas, Sociais e Agrárias, Universidade Federal de Paraíba, Bananeiras, 2009. 
MACHADO, P. G. Dificuldades logísticas no transporte da safra de café do Sul de Minas Gerais. 2018. 44 f. Monografia (Graduação em Ciências Econômicas), Departamento de Ciências Econômicas, Universidade Federal de Ouro Preto, Mariana, 2018.

MATOS, P. F.; PESSÔA, V. L. S. A modernização da agricultura no Brasil e os novos usos do território. Geo UERJ, Rio de Janeiro, v. 2, n. 22, p. 290-322, 2011. Disponível em:

< http://www.e-publicacoes.uerj.br/index.php/geouerj>. Acesso em: 22 fev. 2019.

MEDINA, G. S. Dinâmicas internacionais do agronegócio e implicações para a política agrícola brasileira. Revista de Estudos Sociais, [S./l.], n. 38, v. 19, 2017. Disponível em:

< http://periodicoscientificos.ufmt.br/ojs/index.php/res/article/view/4462>. Acesso em: 22 abr. 2019.

MINISTÉRIO DA INDÚSTRIA, COMÉRCIO EXTERIOR E SERVIÇOS - MDIC/ COMEXSTAT. Exportação unidade federativa. Brasília, 1997, 1998, 1999, 2000, 2001, 2002, 2003, 2004, 2005, 2006, 2007, 2008, 2009, 2010, 2011, 2012, 2013, 2014, 2015, 2016, 2017, 2018. Disponível em:<http://comexstat.mdic.gov.br/pt/geral/2011>. Acesso em: 20 de fev. 2019.

MONIÉ, F. (2011): Dinâmicas produtivas, logística e desenvolvimento territorial: In: COSTA, Pierre; VIDEIRA, Sandra Lúcia; FAJARDO, Sérgio: (RE)leituras da Geografia Econômica. Rio de Janeiro: Letra Capital Editora. p. 145-147.

MORALES, H. D. La Nueva Dinámica del Mercado de los Commodities. Análisis e Investigaciones, $\quad[S .1],$.$\quad v. 1, \quad$ n. $7, \quad$ p. 1-6, 2008. Disponível em: <https://www.bcr.gob.sv/bcrsite/uploaded/content/category/611872653.pdf>. Acesso em: 10 jan. 2019.

PEREIRA, C. S.; HESPANHOL, A. N. Região e regionalizações no Estado de Minas Gerais e suas vinculações com as políticas públicas. Revista Formação, [S./l.], v. 1, n. 22, p.42-70, 2015. Disponível em: <http://revista.fct.unesp.br/index.php/formacao/article/view/3510>. Acesso em: 18 out. 2018.

PEREIRA, L. A. G. Logística de transportes e comercio internacional: os fluxos das exportações e das importações de mercadorias no Norte de Minas Gerais. 2015. 219 f. Tese (Doutorado em Geografia), Instituto de Geografia, Universidade Federal de Uberlândia, Uberlândia, 2015.

PEREIRA, L. A. G.; OLIVEIRA. I. M. Geografia do comércio internacional, exportações e transportes de commodities agrícolas no Brasil. Geosul, Florianópolis, v. 34, n. 71- Dossiê Agronegócios no Brasil, p. 328-355, abril, 2019. Disponível em: <http://doi.org/10.5007/1982-5153.2019v34n71p328>. Acesso em: 10 maio 2019.

PEREIRA, L. A. G.; FERREIRA, W. Redes de transportes e comércio internacional: os fluxos das exportações do setor siderúrgico-metalúrgico no norte de Minas Gerais. RA'EGA: o Espaço Geográfico em Análise, Curitiba, v. 29, p. 64-91, 2013. Disponível em:

< https://revistas.ufpr.br/raega/article/view/29752>. Acesso em: 18 nov. 2018.

PEREIRA, M. F. V. Os agentes do agronegócio e o uso do território no Triângulo Mineiro/Alto Paranaíba: da moderna agricultura de grãos à expansão recente da cana de açúcar. Revista do Departamento de Geografia - USP, v. 23, p. 83-104, 2012. Disponível em: <http://www.revistas.usp.br/rdg/article/view/47206>. Acesso em: 15 ago. 2019. 
PIRES, A. Minas Gerais e a cadeia global da "commodity" cafeeira - 1850/1930. G\&DR, [S./l.], v. 3, n. 2, p. 139-194, 2007. Disponível em:

< http://www.rbgdr.net/o22007/especial.pdf>. Acesso em: 18 jul. 2019.

PONS, Joana Maria Seguí; REYNÉS, Maria Rosa Martínez. Geografia de los transportes. Palma de Mallorca: Universitat de les illes Balears, 2004. 444 p.

SANTOS, M. A Natureza do Espaço: Técnica e Tempo. Razão e Emoção. 4. ed. São Paulo: Editora da Universidade de São Paulo, 2006.

SANTOS, M. Técnica, espaço, tempo; globalização e meio técnico-científico informacional. 3. ed. São Paulo: Ed. Hucitec. 1997.

SILVA, A. T.; et. al. A logística integrada como fonte de vantagem competitiva: o caso de uma empresa do setor de mineração. XXX Encontro Nacional de Engenharia de Produção, São Carlos/SP, 2010. Disponível em: $<\mathrm{http}$ ///www.abepro.org.br/biblioteca/enegep2010_tn_stp_113_741_16501.pdf >. Acesso em: 22 out. 2019.

WAQUIL, P. D.; MIELE, M.; SCHULTZ, G. Mercados e comercialização de produtos agrícolas. Porto Alegre: Editora da UFRGS, 2010.

Recebido em: 06/04/2020 Aprovado para publicação em: 31/07/2020 